\title{
Exceptional summer warming leads to contrasting outcomes for methane cycling in small Arctic lakes of Greenland
}

\author{
Sarah B. Cadieux ${ }^{1, a}$, Jeffrey R. White ${ }^{2}$, and Lisa M. Pratt ${ }^{1}$ \\ ${ }^{1}$ Department of Geological Sciences, Indiana University, Bloomington, IN, USA \\ ${ }^{2}$ School of Public and Environmental Affairs, Indiana University, Bloomington, IN, USA \\ ${ }^{a}$ now at: Earth and Environmental Science, University of Illinois at Chicago, Chicago, IN, USA \\ Correspondence to: Sarah B. Cadieux (sbcadieux@gmail.com)
}

Received: 15 July 2016 - Discussion started: 18 July 2016

Revised: 29 December 2016 - Accepted: 10 January 2017 - Published: 7 February 2017

\begin{abstract}
In thermally stratified lakes, the greatest annual methane emissions typically occur during thermal overturn events. In July of 2012, Greenland experienced significant warming that resulted in substantial melting of the Greenland Ice Sheet and enhanced runoff events. This unusual climate phenomenon provided an opportunity to examine the effects of short-term natural heating on lake thermal structure and methane dynamics and compare these observations with those from the following year, when temperatures were normal. Here, we focus on methane concentrations within the water column of five adjacent small lakes on the icefree margin of southwestern Greenland under open-water and ice-covered conditions from 2012-2014. Enhanced warming of the epilimnion in the lakes under open-water conditions in 2012 led to strong thermal stability and the development of anoxic hypolimnia in each of the lakes. As a result, during open-water conditions, mean dissolved methane concentrations in the water column were significantly $(p<0.0001)$ greater in 2012 than in 2013. In all of the lakes, mean methane concentrations under ice-covered conditions were significantly $(p<0.0001)$ greater than under open-water conditions, suggesting spring overturn is currently the largest annual methane flux to the atmosphere. As the climate continues to warm, shorter ice cover durations are expected, which may reduce the winter inventory of methane and lead to a decrease in total methane flux during ice melt. Under openwater conditions, greater heat income and warming of lake surface waters will lead to increased thermal stratification and hypolimnetic anoxia, which will consequently result in increased water column inventories of methane. This stored methane will be susceptible to emissions during fall over-
\end{abstract}

turn, which may result in a shift in greatest annual efflux of methane from spring melt to fall overturn. The results of this study suggest that interannual variation in ground-level air temperatures may be the primary driver of changes in methane dynamics because it controls both the duration of ice cover and the strength of thermal stratification.

\section{Introduction}

Methane $\left(\mathrm{CH}_{4}\right)$ emissions from freshwater environments are expected to increase with warming climates (Juutinen et al., 2009; Yvon-Durocher et al., 2011, 2014; Tan and Zhuang 2015a, b) but quantitative modeled projections of emissions are poorly constrained (Bastviken et al., 2011; Rasilo et al., 2015; Sepulveda-Jauregui et al., 2015; Tan et al., 2015). Observations of seasonal and annual lake $\mathrm{CH}_{4}$ dynamics in the Arctic are necessary to define source estimates in models and understand the impact warming may have on greenhouse gas emissions. Currently, in the Arctic, small lakes (surface area $<10 \mathrm{~km}^{2}$ ) are abundant (Downing, 2010; Downing et al., 2006) and emit substantially more $\mathrm{CH}_{4}$ per unit area than larger lakes (Bastviken et al., 2004; Cole et al., 2007; Juutinen et al., 2009; Wik et al., 2016), and seasonal variability in $\mathrm{CH}_{4}$ emissions are influenced by energy input and organic carbon availability (Tan et al., 2015). However, climate change will lead to variations in heat balance, temperature profiles, and vertical mixing in lakes (Jankowski et al., 2006; MacIntyre et al., 2009; Hinkel et al., 2012; Butcher et al., 2015), causing many variations to both lake structure (Livingstone 2003; Coats et al., 2006) and $\mathrm{CH}_{4}$ dynamics. 

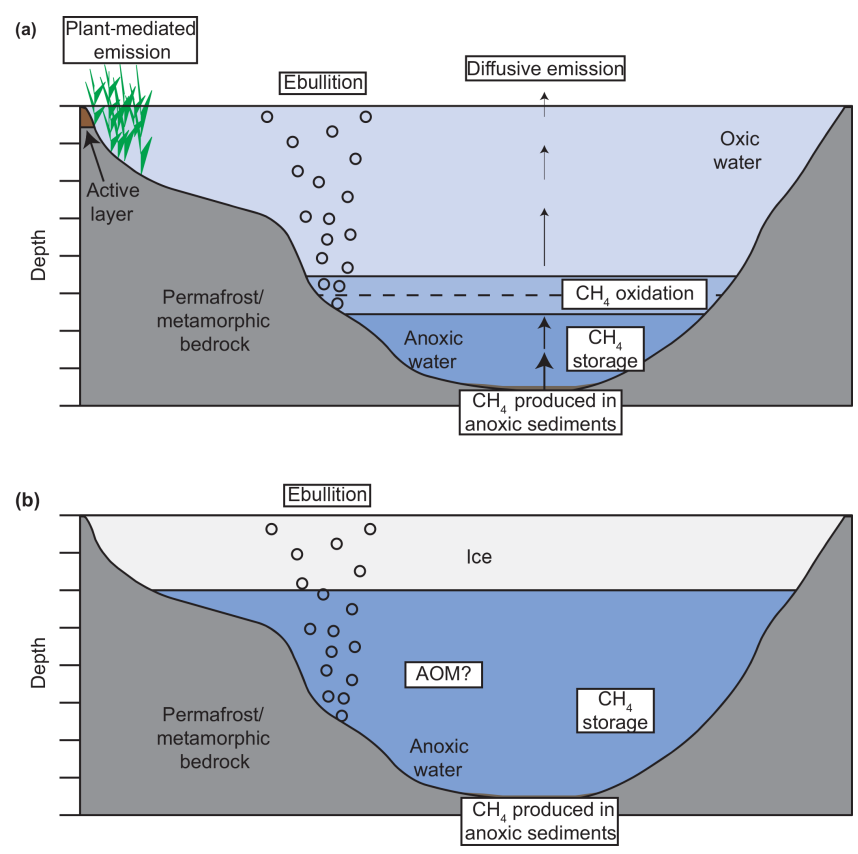

Figure 1. Methane emission pathways and dynamics in a bedrock controlled thermokarst lacustrine system under both open-water and ice-covered conditions.

Microbial production of $\mathrm{CH}_{4}$ by methanogens is dependent upon anoxia, temperature, and the amount and quality of organic carbon substrates (Liikanen et al., 2003; Kankaala et al., 2006; Duc et al., 2010; Borrel et al., 2011). A large proportion of the $\mathrm{CH}_{4}$ produced in lakes is consumed by aerobic or anaerobic oxidation (Frenzel et al., 1990; Bastviken et al., 2002; Kankaala et al., 2007; Dzyuban, 2010; Martinez-Cruz et al., 2015). Aerobic microbial oxidation of methane (MOx) depends on the availability of both $\mathrm{CH}_{4}$ and $\mathrm{O}_{2}$, wherein higher MOx rates are usually found at the oxic-anoxic interface, where both $\mathrm{CH}_{4}$ and $\mathrm{O}_{2}$ are present in high concentrations (Bastviken et al., 2002; Dzyuban, 2010). Excess $\mathrm{CH}_{4}$ that escapes MOx and reaches the upper mixed layer of the water column (epilimnion) is available for emission to the atmosphere by molecular diffusion under open-water conditions. Emission by ebullition and plants results in a direct flux of $\mathrm{CH}_{4}$ to the atmosphere with limited oxidation in the water column (Keppler et al., 2006; Walter et al., 2006, 2007; Nisbet et al., 2009; Wik et al., 2013; Greene et al., 2014).

In lakes, the amounts of $\mathrm{CH}_{4}$ in the water column (hereafter referred to as inventory) and $\mathrm{CH}_{4}$ available for diffusive emissions (hereafter referred to as active $\mathrm{CH}_{4}$ ) are strongly influenced by thermal stratification and seasonal overturns (Kankaala et al., 2007; López Bellido et al., 2009; Encinas Fernandez et al., 2014). Arctic lakes that are deep enough to stratify are usually dimictic (spring and fall turnover) or cold monomictic (spring turnover) in areas without perennial ice cover. During thermal stratification, a lack of mixing between the epilimnion and anoxic hypolimnion sup- presses gas transfer between these layers, allowing $\mathrm{CH}_{4}$ to accumulate below the oxycline (hereafter referred to as storage; Fig. 1; Bastviken et al., 2004; Sepulveda-Jauregui et al., 2015). During mixing from fall turnover, all $\mathrm{CH}_{4}$ previously stored in the hypolimnion is susceptible to MOx and/or diffusion (Encinas Fernandez et al., 2014). Under ice cover, $\mathrm{CH}_{4}$ can accumulate and is either stored under ice or within the ice (Fig. 1; Walter et al., 2006; Walter Anthony et al., 2012; Sepulveda-Jauregui et al., 2015). In spring, the break-up of the ice and mixing allows stored $\mathrm{CH}_{4}$ to be oxidized or emitted from the system through diffusion or ebullition (Juutinen et al., 2009; López Bellido et al., 2009; Karlsson et al., 2013; Greene et al., 2014; Jammet et al., 2015). Emissions of stored $\mathrm{CH}_{4}$ during overturn events accounts for up to $40 \%$ of the total annual flux in lakes globally (Michmerhuizen et al., 1996; Juutinen et al., 2009; López Bellido et al., 2009; Encinas Fernandez et al., 2014; Jammet et al., 2015).

Over the last three decades, increasing atmospheric temperatures have resulted in increased lake temperatures and decreases in ice cover (Weyhenmeyer et al., 2011; Kraemer et al., 2015). Warming of surface waters will lead to increased thermal stratification and hypolimnetic anoxia, which should cause higher inventories of dissolved $\mathrm{CH}_{4}$ stored in the hypolimnion of the water column. In addition to changes to thermal structure, warming and thawing of permafrost in the Arctic may allow organic carbon, nutrients, and ions that were previously frozen in sediments to be transported into aquatic systems and become available for microbial utilization (Kokelj et al., 2009; Lougheed et al., 2011; Weyhenmeyer et al., 2011). Experimental laboratory incubation studies have also demonstrated that microbial $\mathrm{CH}_{4}$ production significantly increases with increased temperature (Duc et al., 2010; Lofton et al., 2013; Fuchs et al., 2016).

On the ice-free margin of southwestern Greenland, hundreds of thousands of Holocene lakes perched on continuous permafrost cover the landscape (Anderson et al., 2001; Anderson and Stedmon, 2007; Jorgensen and Andreasen, 2007). As a result of amplified warming in the Arctic over the past 20 years (IPCC, 2013), Greenland has experienced significant mass loss of the Greenland Ice Sheet (GIS; Nghiem et al., 2012; van As et al., 2012; Hall et al., 2013; Hanna et al., 2013, 2014). Despite the abundance of lakes on the ice-free margin of Greenland and intense changes to the landscape as the result of warming, there are only a few published studies that have measured $\mathrm{CH}_{4}$ in Greenlandic lakes (Walter Anthony et al., 2012; Webster et al., 2015; Cadieux et al., 2016; Goldman et al., 2016).

The anomalously warm summer in Greenland 2012, which resulted in substantial surface melt of the GIS (Nghiem et al., 2012; Hanna et al., 2014), provides an opportunity to examine the effects of surface water heating on $\mathrm{CH}_{4}$ dynamics in lakes. In this study, we quantify the depth inventories of $\mathrm{CH}_{4}$ under both open-water and ice-covered conditions for five adjacent small lakes on the ice-free margin of southwestern Greenland from 2012 to 2014. In doing so, we are able to 
Table 1. Morphometrics and median physicochemical characteristics of lakes under open-water conditions in 2012.

\begin{tabular}{lrrrrrrr}
\hline & $\begin{array}{r}Z_{\max } \\
(\mathrm{m})\end{array}$ & $\begin{array}{r}\text { Fetch } \\
(\mathrm{m})\end{array}$ & $\begin{array}{r}\text { Surface } \\
\text { area (ha) }\end{array}$ & $\begin{array}{r}\text { Volume } \\
\left(\mathrm{m}^{3}\right)\end{array}$ & $\mathrm{pH}$ & $\begin{array}{r}\text { Specific } \\
\text { conductivity } \\
\left(\mathrm{mS} \mathrm{cm}^{-1}{ }^{\circ} \mathrm{C}\right)\end{array}$ & $\begin{array}{r}\text { DOC } \\
\left(\mathrm{mg} \mathrm{L}^{-1}\right)\end{array}$ \\
\hline EVV Upper* & 5.5 & 68 & 0.22 & 5200 & $7.0(11)$ & $0.7(11)$ & $38.7(4)$ \\
EVV Lower & 4.5 & 180 & 1.5 & 31000 & $8.9(10)$ & $1.2(10)$ & $38.4(2)$ \\
Teardrop* & 5.25 & 160 & 0.97 & 34000 & $9.2(11)$ & $4.3(11)$ & $92.0(4)$ \\
Potentilla* & 8.0 & 280 & 1.6 & 160000 & $7.2(15)$ & $0.4(15)$ & $11.4(3)$ \\
South Twin & 5.5 & 310 & 3.1 & 120000 & $7.9(11)$ & $4.0(11)$ & $20.5(3)$ \\
\hline
\end{tabular}

Sample size is in parentheses. * Can also be found in Cadieux et al. (2016).
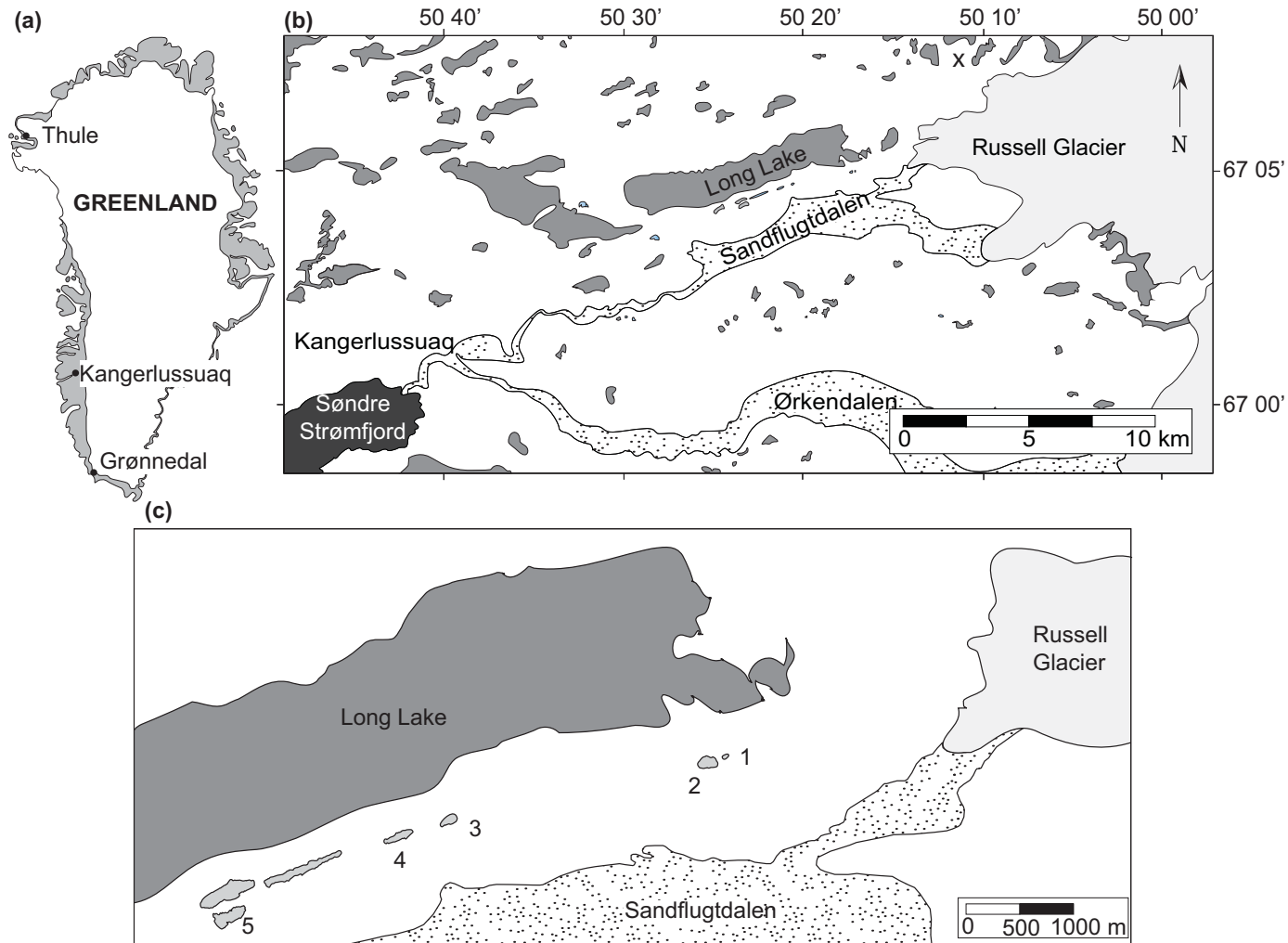

Figure 2. (a) Greenland, showing Kangerlussuaq. (b) Regional map of Kangerlussuaq and the inland ice margin, including Sandflugtdalen and Ørkendalen, which are two major proglacial valley sandur systems. X marks the location of the Geological Survey of Denmark and Greenland (GEUS) weather station. (c) Study area map of lakes relative to the Russell Glacier, Long Lake, and Sandflugtdalen sandur. (1) EVV Upper lake, (2) EVV Lower lake, (3) Teardrop lake, (4) Potentilla lake, and (5) South Twin lake. Figure is modified from Cadieux et al. (2016).

look at differences in $\mathrm{CH}_{4}$ spatially among the lakes, seasonally by comparing open-water conditions to ice-covered conditions, and annually. The study lakes are ice-covered for 910 months of the year, leading us to predict that methane concentrations would be significantly greater under ice-covered conditions as opposed to open-water conditions. Under openwater conditions, we hypothesized that warmer conditions in the summer of 2012 would lead to increased thermal stratification and significantly greater $\mathrm{CH}_{4}$ concentrations under open-water conditions than in 2013.

\section{Study area}

The study area lies between the village of Kangerlussuaq, Greenland, at the head of Søndre Strømfjord and the active terminus of the Russell Glacier (Fig. 2). The region has continuous permafrost extending from $50 \mathrm{~cm}$ below the surface to $130 \mathrm{~m}$ at Kangerlussuaq and $500 \mathrm{~m}$ at the ice sheet (Jorgensen and Andreasen, 2007). Soils in the region are not well developed, composed of till and glaciofluvial deposits (Van Tatenhove and Olesen, 1994). Precipitation in the Kangerlus- 


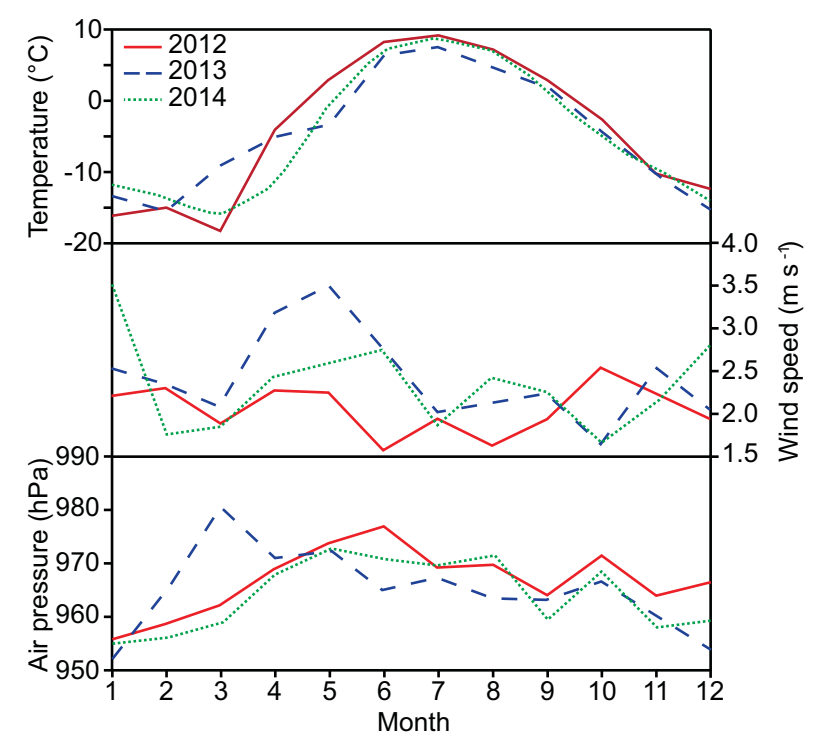

Figure 3. Mean monthly temperature, wind speed, and air pressure for Kangerlussuaq from 2012 (red solid line), 2013 (blue dashed line) and 2014 (green dotted line). Data from the Program for Monitoring of the Greenland Ice Sheet (PROMICE) and the Greenland Analog Project (GAP) were provided by the Geological Survey of Denmark and Greenland at http://www.promice.dk.

suaq region is low, with annual precipitation $<150 \mathrm{~mm} \mathrm{yr}^{-1}$. Dwarf shrubs (Salix, Vaccinium, and Betula) and graminoids (Carex and Calamagrostis) dominate the tundra vegetation in the region.

This paper focuses on five small lakes (surface area $<3$ ha, maximum depth $<8 \mathrm{~m}$ ), with a range of different morphometries and aquatic chemistries (Table 1). The lake names used herein (EVV Upper Lake, EVV Lower Lake, Teardrop Lake, Potentilla Lake, and South Twin Lake) are informal, based on local surficial features. The study lakes are part of a series of lakes within a narrow valley overlying a structural shear zone extending from the Russell Glacier to the Søndre Strømfjord (Fig. 2). The lakes are, at most, $6 \mathrm{~km}$ apart and are subject to the same climatic forcing. All lakes in the study are dimictic, exhibiting ice cover from late October to early June. Currently the study lakes are all hydrologically closed basins, with no active inflow or outflow channels observed from 2011 to 2014. Groundwater seepage into the lakes is assumed to be limited due to continuous permafrost.

In summer 2012, a blocking high-pressure system formed a heat dome over Greenland, leading to widespread surface melting of the GIS (Hall et al., 2013; Hanna et al., 2014; Nghiem et al., 2012). As a result, this circulation pattern produced mean daily ground-level air temperatures in Kangerlussuaq that were the highest on record (Hanna et al., 2014). Weather data from a local Geological Survey of Denmark and Greenland (GEUS) station (van As et al., 2011; Fig. 2) showed that mean monthly ground-level temperatures for June-August in 2012 were $\sim 2{ }^{\circ} \mathrm{C}$ higher than in
2013 (Fig. 3). Correspondingly, mean air pressure from May to August of 2012 was higher than in 2013 (Fig. 3). Mean monthly wind speeds in the Kangerlussuaq region ranged from 1.52 in June 2012 to $3.51 \mathrm{~m} \mathrm{~s}^{-1}$ in May of 2013 (Fig. 3). At the Kangerlussuaq airport, average temperatures from May to August of 2013 were within the range observed from 1996 to 2011, suggesting 2013 weather is typical for the region (data retrieved from www.weatherunderground.com).

\section{Methods}

\subsection{Sample collection and water chemistry analysis}

Lakes were sampled in July of 2012 and 2013 and in April of 2013 and 2014 in order to measure both summer and winter stratification. Hereafter, July samplings will be referred to as open water and April samplings as ice-covered. Only EVV Upper lake and Potentilla lake were sampled during all four sampling dates. All samples and measurements were taken at a location above maximum water depth $\left(Z_{\max }\right)$. Under openwater conditions, samples and measurements were collected using an inflatable Alpaca raft (Anchorage, AK, USA), and under ice-covered conditions, when each lake was covered by $\sim 2 \mathrm{~m}$ of ice, a hole $(\sim 30 \mathrm{~cm}$ in diameter) was augured through the ice in order to sample. Temperature $\left(T,{ }^{\circ} \mathrm{C}\right), \mathrm{pH}$, dissolved oxygen (DO, $\left.\mathrm{m} \mathrm{L}^{-1}\right)$, oxidation-reduction potential $(\mathrm{ORP}, \mathrm{mV})$ and specific conductivity $\left(\mathrm{mS} \mathrm{cm}^{-1}\right)$ were measured using a YSI 6093 data sonde (Yellow Springs Inc., Yellow Springs, OH, USA) deployed at vertical intervals of $0.5 \mathrm{~m}$ depth.

Water for chemical analysis was collected from the water column using a Narrow Diameter Supernova ${ }^{\mathrm{TM}}$ electronic submersible pump. Samples were frozen, and transported to Indiana University, where all chemical analyses were conducted. Dissolved organic carbon (DOC) was analyzed from filtered samples that were acidified using hydrochloric acid $(\mathrm{HCl})$, and analyzed via high-temperature oxidation using a Shimadzu total organic carbon analyzer following methods described in Oviedo-Vargas et al. (2013) (corresponding method detection limit $\left.(\mathrm{MDL})=0.15 \mathrm{mg} \mathrm{CL}^{-1}\right)$. Concentrations of ions were analyzed using a Dionex ICS 2000 ion chromatograph using a CS12A analytical cation column, CSRS $3004 \mathrm{~mm}$ suppressor, and $20 \mathrm{mM}$ methanesulfonic acid eluent for cations and AS11-HC analytical anion column, ASRS $4 \mathrm{~mm}$ suppressor, and $30 \mathrm{mM}$ potassium hydroxide eluent for anions.

\section{2 $\mathrm{CH}_{4}$ collection}

With the exception of Potentilla lake under ice-covered conditions in 2014, water samples for dissolved $\mathrm{CH}_{4}$ in the water column were collected using an electronic submersible pump. Samples were collected at $0.25-1.0 \mathrm{~m}$ intervals through the water column and were immediately stripped in the field using a headspace-equilibrium technique 
(Westendorp, 1985) to extract $\mathrm{CH}_{4}$ from water. At each depth interval, $500 \mathrm{~mL}$ of water was collected into a $1 \mathrm{~L}$ Erlenmeyer flask and vigorously shaken for $1 \mathrm{~min}$. Headspace gas in the flask was displaced into a Cali-5-Bond bag using surficial lake water (Cadieux et al., 2016). Under ice-covered conditions in 2014, dissolved $\mathrm{CH}_{4}$ in Potentilla lake was collected using a string of passive diffusion bags (PDBs) deployed in the lake for 5 days in order to obtain a high-resolution profile of dissolved $\mathrm{CH}_{4}$ in the water column (Goldman et al., 2016). The PDBs are composed of a polyethylene membrane with a protective plastic mesh and are commercially available from EON Products Inc. (Georgia, USA). After 5 days, PDBs were retrieved from the lake and dissolved gas was sampled immediately in the field using the equilibrium gas stripping method described above. Further details regarding PDB methodology, preparation, and applicability can be found in Goldman et al. (2016).

Profundal sediment samples were taken from $Z_{\max }$ of each lake during ice-covered conditions and open-water conditions in 2013 using a Wildco push-coring device. Cores were transferred back to the laboratory at Kangerlussuaq International Science Support (KISS) facility and immediately refrigerated at $4{ }^{\circ} \mathrm{C}$ and processed within $24 \mathrm{~h}$ of collection. Dissolved gas in the sediment was sampled using an equilibrium gas stripping method similar to that used for the water column $\mathrm{CH}_{4}$. Sediment cores were subsectioned into $6-10 \mathrm{~cm}$ intervals and each subsection was put into a $8 \mathrm{~L}$ Nalgene bottle with zero- $\mathrm{CH}_{4}$ water to create $2 \mathrm{~L}$ sediment-water slurry, which was vigorously hand shaken for $5 \mathrm{~min}$ to displace gas from the sediment-water slurry into the headspace (Cadieux et al., 2016). The volume of pore water in the sediment core was calculated by drying an additional subsection of sediment. The concentration of $\mathrm{CH}_{4}$ in the sediment cores was calculated as moles of $\mathrm{CH}_{4}$ per unit volume of pore water in the sediment.

Littoral sediment $\mathrm{CH}_{4}$ bubble samples were collected during open-water conditions of both 2012 and 2013 by physically disturbing the sediment in order to release entrained gas bubbles. Gas bubbles were collected using a large plastic funnel $(28 \mathrm{~cm}$ diameter) with a gas-tight sampling tube and three-way Luer Lock valve attached to the neck (Cadieux et al., 2016). We were unable to quantify the volume of sediment samples; therefore, concentrations of $\mathrm{CH}_{4}$ in gas collected from littoral sediments cannot be converted into pool size of $\mathrm{CH}_{4}$ in the littoral sediments and are only an approximation of $\mathrm{CH}_{4}$ concentration.

\subsection{Concentration of $\mathrm{CH}_{4}$}

The concentrations of water column $\mathrm{CH}_{4}$ and sediment $\mathrm{CH}_{4}$ were measured using a Los Gatos Research (LGR) Methane Carbon Isotope Analyzer (MCIA; LGR, Mountain View, CA, USA) that was operated at KISS (Cadieux et al., 2016). All samples were processed within $24 \mathrm{~h}$ of collection. The total concentration of $\mathrm{CH}_{4}$ in each sample was corrected for dilu- tion and calculated from the sum of the measured headspace partial pressure and the dissolved $\mathrm{CH}_{4}$ remaining after gas stripping, according to Henry's law using values from Lide and Fredrikse (1995). Instrumental uncertainty on $\mathrm{CH}_{4}$ concentrations from the MCIA was $\pm 0.5 \mathrm{ppmv}$, which is 1 standard deviation of the values for gas standards analyzed during sample runs.

\subsection{Inventory of dissolved $\mathrm{CH}_{4}$}

Bathymetric data were collected under open-water conditions in 2013 using a LOWRANCE HDS-5 Gen2 depthsonar built with GPS and processed by ciBioBase software by Contour Innovations LLC (Minneapolis, MN, US). The area and volume of water were derived and measured from bathymetric data. The total inventory of dissolved $\mathrm{CH}_{4}$ in each lake was calculated by multiplying $\mathrm{CH}_{4}$ concentrations for each depth interval by the volume of each depth interval. It was assumed that $\mathrm{CH}_{4}$ concentrations within each depth interval were homogenous both horizontally and vertically. During open-water conditions, the depth intervals for active and storage pools were defined by redox conditions, where the storage depths are defined as intervals with DO $<1 \mathrm{mg} \mathrm{L}^{-1}$. The active depths were associated with the oxic epilimnion, where dissolved gases are susceptible to diffusive exchange with the atmosphere and exposed to atmospheric oxygen. Under ice cover, the size of the $\mathrm{CH}_{4}$ storage pool was assumed to be that contained in the volume of water below ice.

\subsection{Statistical analyses}

Statistical analyses were made using IBM SPSS Statistics. Concentrations of $\mathrm{CH}_{4}$ and chemical variables for all study lakes during each season were assessed for normal distribution via the Kolmogorov-Smirnov test, and were found to be non-normally distributed. Student's $t$ test of unequal variance was used for testing statistically significant differences in concentrations of $\mathrm{CH}_{4}$ between open-water and ice-covered conditions, as well as from one year to another. Systematic changes in aquatic chemistry and $\mathrm{CH}_{4}$ concentrations were analyzed using linear regression in order to assess whether $\mathrm{CH} 4$ concentrations were related to variables such as DO, temperature, DOC, and conductivity.

\section{Results}

\subsection{Thermal structure and DO profiles}

Under open-water conditions, all lakes were thermally stratified in 2012 (Fig. 4). Thermal stratification, expressed in terms of temperature difference $\left(\Delta T=T_{0 \mathrm{~m}}-T_{z \max }\right)$, was $>12{ }^{\circ} \mathrm{C}$ in all lakes except for EVV Lower lake, where $\Delta T \approx 7^{\circ} \mathrm{C}$. For all lakes under open-water conditions, epilimnetic temperatures were significantly warmer $(n=30$, 
Table 2. Seasonal and annual variation in median specific conductivity and DOC.

\begin{tabular}{|c|c|c|c|c|}
\hline & $\begin{array}{r}\text { Open water } \\
2012^{*}\end{array}$ & $\begin{array}{r}\text { Ice cover } \\
2013\end{array}$ & $\begin{array}{r}\text { Open water } \\
2013\end{array}$ & $\begin{array}{r}\text { Ice cover } \\
2014\end{array}$ \\
\hline & \multicolumn{4}{|c|}{ Specific conductivity $\left(\mathrm{mS} \mathrm{cm}^{-1}\right)$} \\
\hline EVV Upper lake & $0.7(10)$ & $1.5(10)$ & $0.5(11)$ & $1.0(10)$ \\
\hline EVV Lower lake & $1.2(8)$ & $2.9(7)$ & $1.0(9)$ & n.d. \\
\hline Teardrop lake & $4.3(10)$ & n.d. & $1.9(11)$ & $3.1(10)$ \\
\hline Potentilla lake & $0.4(15)$ & $0.5(15)$ & $0.3(16)$ & $0.4(13)$ \\
\hline \multirow[t]{2}{*}{ South Twin lake } & $4.0(10)$ & $4.0(9)$ & $1.2(9)$ & n.d. \\
\hline & \multicolumn{4}{|c|}{$\operatorname{DOC}\left(\mathrm{mg} \mathrm{L}^{-1}\right)$} \\
\hline EVV Upper lake & $39(4)$ & $79(3)$ & $48(4)$ & $76(6)$ \\
\hline EVV Lower lake & $38(2)$ & $80(2)$ & $49(2)$ & n.d. \\
\hline Teardrop lake & $92(3)$ & n.d. & $58(4)$ & $77(3)$ \\
\hline Potentilla lake & $11(3)$ & $17(4)$ & $11(3)$ & $12(9)$ \\
\hline South Twin lake & $21(3)$ & $110(2)$ & $48(3)$ & n.d. \\
\hline
\end{tabular}

n.d. refers to seasons when a given lake was not measured. Sample size is in parentheses.

* Open-water conditions for EVV Upper lake, Teardrop lake, and South Twin lake can also be

found in Cadieux et al. (2016).
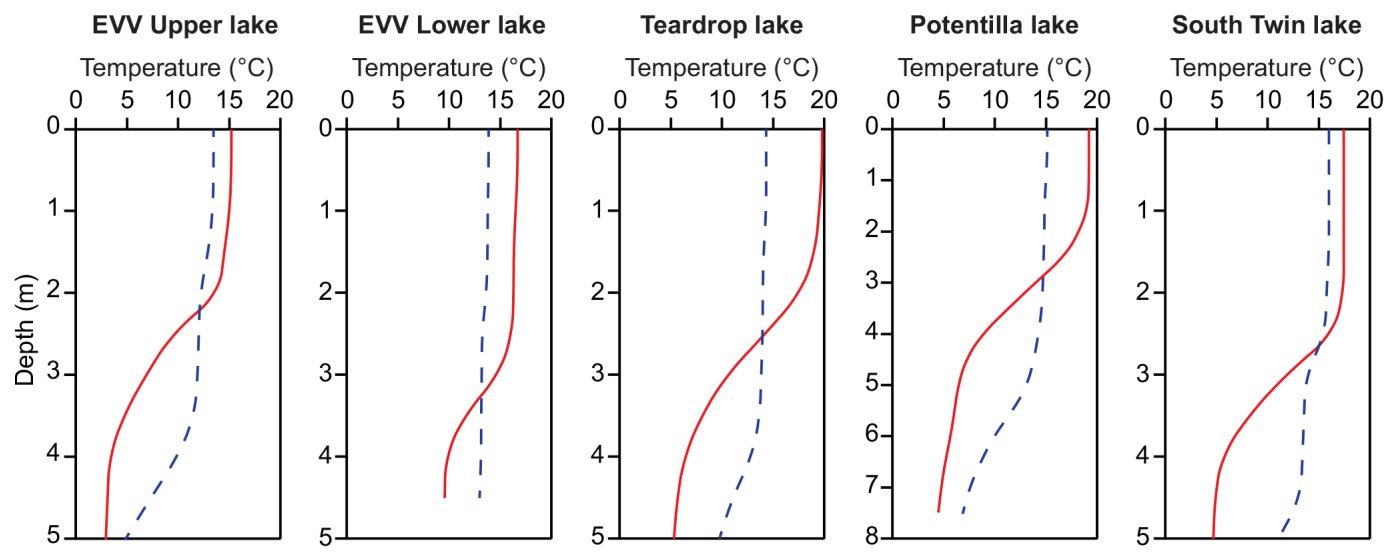

Figure 4. Profiles of temperature under open-water conditions in 2012 (red solid line) and 2013 (blue dashed line).

$p<0.0001)$ and bottom waters were cooler in 2012 than in 2013 (Fig. 4). Under open-water conditions in 2013, various levels of thermal stratification were observed, ranging from thermally stratified in EVV Upper lake and Potentilla lake $\left(\Delta T \approx 9^{\circ} \mathrm{C}\right)$ to isothermal in EVV Lower lake $\left(\Delta T \approx 1^{\circ} \mathrm{C}\right.$; Fig. 4). Under ice-covered conditions in both 2013 and 2014, lakes were nearly isothermal $\left(\Delta T<2{ }^{\circ} \mathrm{C}\right)$ except for Potentilla lake which was weakly thermally stratified under ice cover, with $\Delta T \approx 4^{\circ} \mathrm{C}$ in both years.

Clinograde DO profiles were observed in all lakes under open-water conditions in 2012, wherein DO was saturated and in equilibrium with the atmosphere in the surface waters and became increasingly undersaturated down the water column (Fig. 5). Anoxia (DO $<0.5 \mathrm{mg} \mathrm{L}^{-1}$ ) was measured in the bottom waters of all lakes except for Teardrop lake. In EVV Upper lake, Potentilla lake, and South Twin lake, the bottom 2 to $2.5 \mathrm{~m}$ of the water column was anoxic. Similar clinograde DO trends were observed under open-water conditions in 2013, although stratification was weaker (Fig. 5) and anoxia was limited to the bottom $1 \mathrm{~m}$ of the water column in EVV Upper lake and Potentilla lake. All lakes exhibited complete anoxia below the ice with the exception of Potentilla lake in both years. Measurable DO was observed under ice in Potentilla lake, with a clinograde profile from suboxic conditions $\left(7.0-5.0 \mathrm{mg} \mathrm{L}^{-1}\right)$ below the ice to $4.5 \mathrm{~m}$ and anoxic conditions from $5.5 \mathrm{~m}$ to the sediment-water interface.

\subsection{Aquatic chemistry}

Ionic composition varied markedly lake to lake as well as seasonally and annually (Table 2). According to a salinity classification scheme based on specific conductivity (Stewart and Kantrud, 1971), under open-water conditions in 


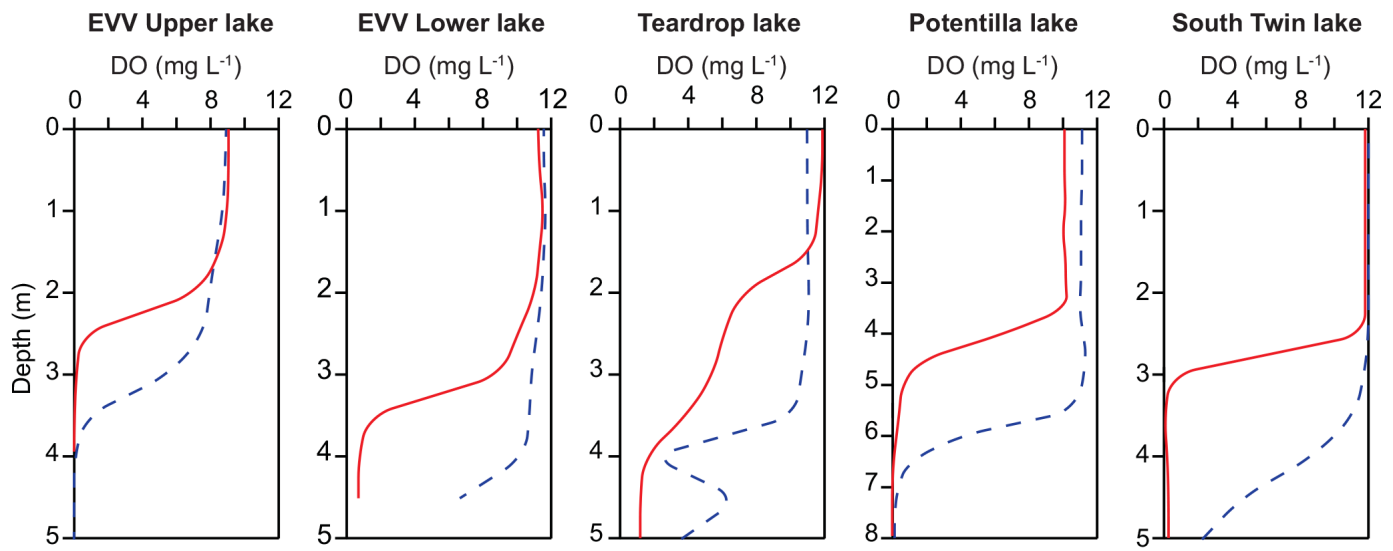

Figure 5. Profiles of DO under open-water conditions in 2012 (red solid line) and 2013 (blue dashed line).

Table 3. Concentrations of $\mathrm{CH} 4(\mu \mathrm{M})$ in surface waters $(0.5 \mathrm{~m})$ under open-water conditions in 2012 and 2013.

\begin{tabular}{lrr}
\hline & 2012 & 2013 \\
\hline EVV Upper & 2.7 & 0.9 \\
EVV Lower & 11.5 & 2.7 \\
Teardrop & 27.8 & 2.4 \\
Potentilla & 2.6 & 1.3 \\
South Twin & 4.3 & 3.5 \\
\hline
\end{tabular}

2012, two of the study lakes were dilute $\left(0.04-0.5 \mathrm{mS} \mathrm{cm}^{-1}\right.$; EVV Upper and Potentilla), one was slightly brackish $(0.5-$ $2 \mathrm{mS} \mathrm{cm}^{-1}$; EVV Lower), and two were moderately brackish salinity, with maximum specific conductivity exceeding $2 \mathrm{mS} \mathrm{cm}^{-1}$ (Table 2). The anion abundance followed $\mathrm{HCO}_{3}^{-}>\mathrm{DOC}^{-} / \mathrm{Cl}^{-}>\mathrm{SO}_{4}^{2-}$ in most of lakes, regardless of conductivity. $\mathrm{DOC}^{-}$represents the estimated charge on DOC based upon the anionic charge deficit (Driscoll and Newton, 1985; Fig. 6). EVV Upper lake was the only lake where $\mathrm{SO}_{4}^{2-}>\mathrm{Cl}^{-}$. Sulfate accounted for $12 \%$ of the total anion abundance in EVV Upper lake, relative to $<3 \%$ in the other lakes. Cation abundance in dilute lakes followed $\mathrm{Ca}^{2+}>\mathrm{Mg}^{2+}>\mathrm{Na}^{+}>\mathrm{K}^{+}$, whereas in slightly brackish lakes, $\mathrm{Mg}^{2+}>\mathrm{Na}^{+}>\mathrm{Ca}^{2+}>\mathrm{K}^{+}$was observed (Fig. 6). Overall, conductivity and ionic compositions were higher under ice-covered conditions than open-water conditions (Table 2). However, under open-water conditions in 2012, mean specific conductivity was significantly higher in all lakes than in $2013(n=53, p<0.0001)$.

Under open-water conditions in 2012, concentrations of DOC ranged from median of $11 \mathrm{mg} \mathrm{L}^{-1}$ (Potentilla lake) to $92 \mathrm{mg} \mathrm{L}^{-1}$ (Teardrop lake; Table 2). Under ice-covered conditions, DOC was higher than open-water conditions (Table 2). No consistent trends were observed for DOC between open-water conditions in 2012 and 2013.
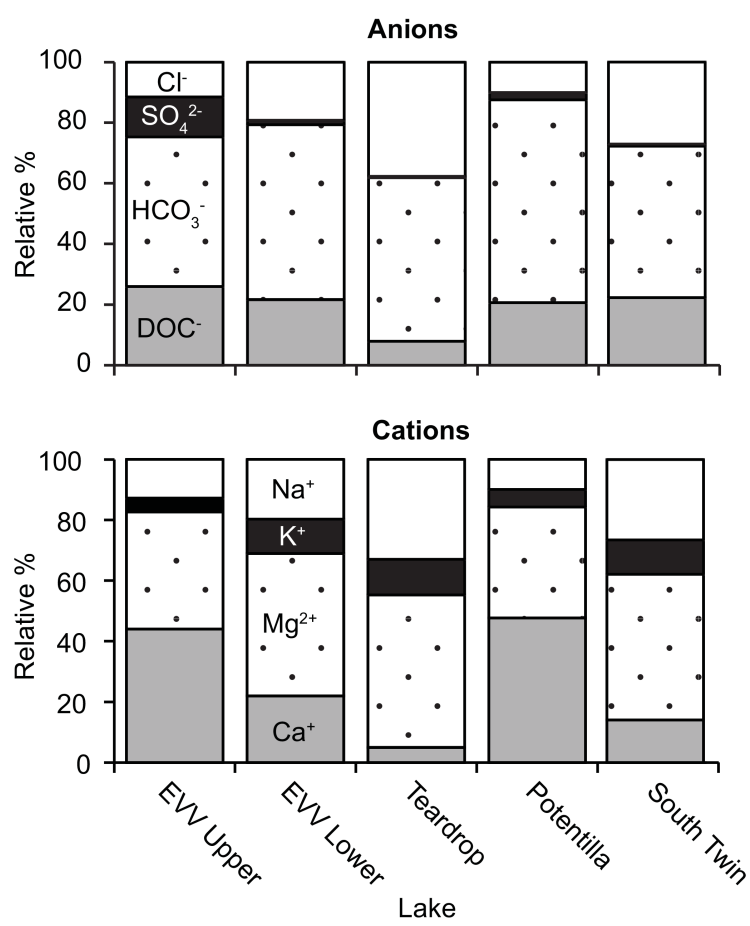

Figure 6. Relative percentages of median total charge associated with anions and cations in water samples from each of the study lakes. We assign the equivalents of missing anionic charge to DOC (Driscoll and Newton, 1985). In all study lakes, $\mathrm{HCO}_{3}^{-}$was the dominant anion. $\mathrm{SO}_{4}^{2-}$ was the least abundant anion in all lakes except EVV Upper lake. There was no dominant cation from lake to lake.

\subsection{Concentrations of $\mathrm{CH}_{4}$}

\subsubsection{Dissolved water column $\mathrm{CH}_{4}$}

Concentrations of dissolved $\mathrm{CH}_{4}$ were significantly greater under open-water conditions in 2012 than in $2013(n=38$, $p=0.008$; Fig. 6). Under open-water conditions in 2012 , 


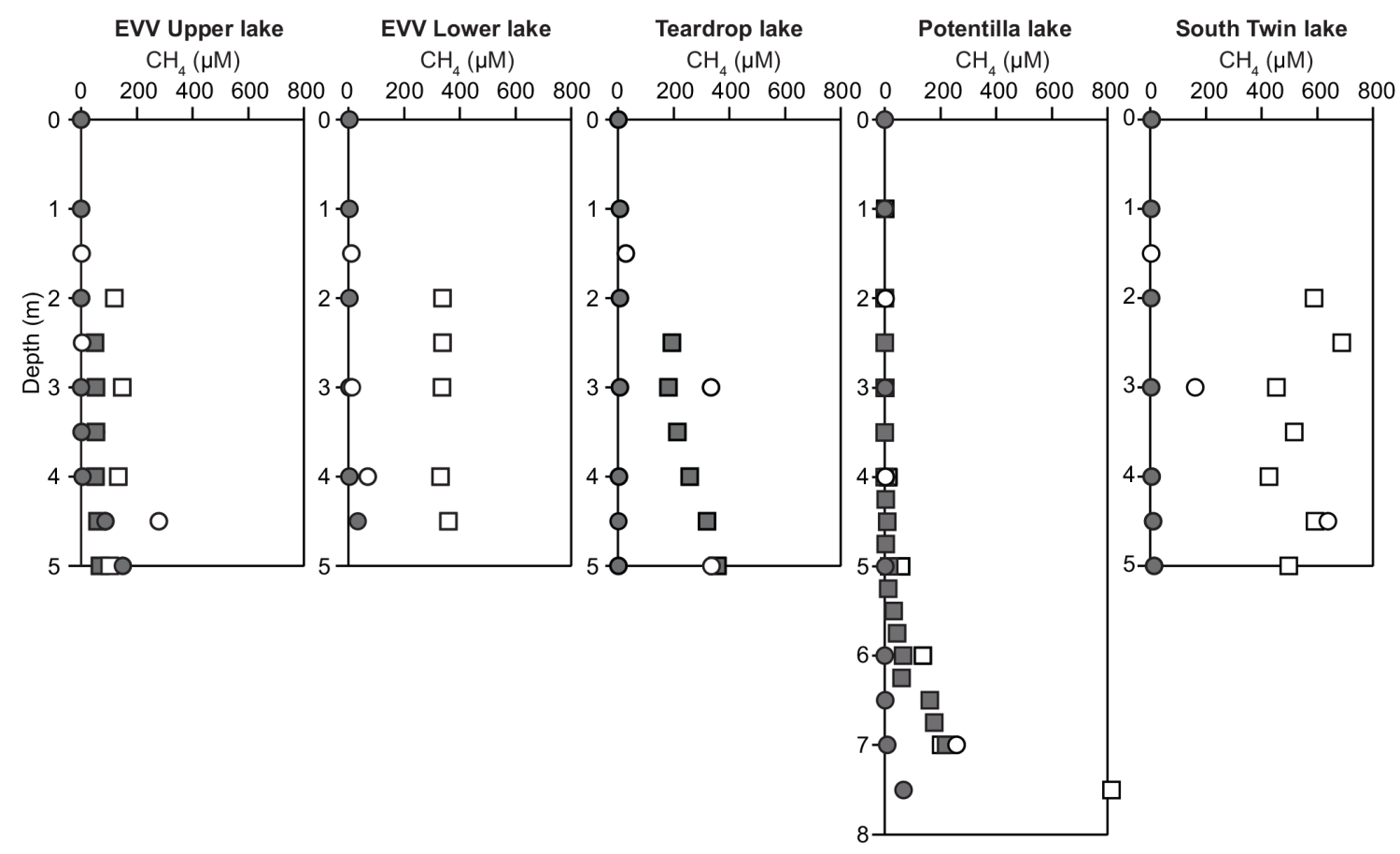

Figure 7. Profiles of dissolved $\mathrm{CH}_{4}$ under open-water conditions (circles) in July 2012 (open) and July 2013 (closed) and ice-covered conditions (squares) in April 2013 (open) and April 2014 (closed). Concentrations of $\mathrm{CH}_{4}$ under open-water conditions in 2013 and icecovered conditions in 2014 can also be seen in Cadieux et al. (2016).

dissolved $\mathrm{CH}_{4}$ concentrations in the surface waters of the study lakes ranged from 1.2 to $28 \mu \mathrm{M}$ (Fig. 7; Table 3). In all of the lakes, $\mathrm{CH}_{4}$ concentrations increased down the water column and were greatest in the bottom waters (Fig. 7). The highest concentration of dissolved $\mathrm{CH}_{4}(640 \mu \mathrm{M})$ was observed at $4.5 \mathrm{~m}$ in South Twin lake. Similar to 2012, in $2013 \mathrm{CH}_{4}$ concentrations increased down the water column in all lakes except for Teardrop lake. Under open-water conditions in 2013, concentrations of $\mathrm{CH}_{4}$ at the water-air interface ranged from 0.88 to $3.5 \mu \mathrm{M}$ (Fig. 7). In Teardrop lake, $\mathrm{CH}_{4}$ was $<10 \mu \mathrm{M}$ though the water column, ranging from 1.4 to $8.1 \mu \mathrm{M}$ (Fig. 7). The highest concentration of $\mathrm{CH}_{4}$ $(150 \mu \mathrm{M})$ was observed at $5.0 \mathrm{~m}$ in EVV Upper lake.

Under ice-covered conditions, the mean concentrations of dissolved $\mathrm{CH}_{4}$ were significantly greater than under openwater conditions ( $n=29, p<0.0001$; Fig. 7). In 2013, $\mathrm{CH}_{4}$ concentrations under ice cover were relatively uniform down the water column in EVV Upper lake $(102-150 \mu \mathrm{M})$ and EVV Lower lake $(340-360 \mu \mathrm{M})$ and ranged from 450 to $690 \mu \mathrm{M}$ in South Twin lake. Only in Potentilla lake did $\mathrm{CH}_{4}$ increase down the water column from $1.3 \mu \mathrm{M}$ under the ice to $812 \mu \mathrm{M}$ at the sediment-water interface (Fig. 7). The mean concentrations of dissolved $\mathrm{CH}_{4}$ under ice cover in 2013 were significantly greater than in $2014(n=29$; $p<0.0001$; Fig. 7). In 2014, dissolved $\mathrm{CH}_{4}$ concentrations increased down the water column from below ice cover to the sediment-water interface in all of the three lakes, from
49 to $68 \mu \mathrm{M}$ in EVV Upper lake, 190 to $360 \mu \mathrm{M}$ in Teardrop lake, and 0.3 to $220 \mu \mathrm{M}$ in Potentilla lake (Fig. 7).

Linear relationships between aquatic chemistry and $\mathrm{CH}_{4}$ concentrations were weak (Fig. 8; $r^{2}$ values for regressions ranged from 0.20 to 0.35 ). The highest $\mathrm{CH}_{4}$ concentrations were correlated with both lower temperatures and lower DO; however, the lowest $\mathrm{CH}_{4}$ concentrations did not correlate with highest temperatures or DO (Fig. 8a and b). Overall, high concentrations of $\mathrm{CH}_{4}$ were related to high conductivity and DOC (Fig. 8c and d).

\subsubsection{Whole-lake inventories and pool sizes of $\mathrm{CH}_{4}$}

In all the lakes, the total inventory of $\mathrm{CH}_{4}$ in the water column was higher under ice-covered conditions in 2013 and lower under open-water conditions in 2013 (Fig. 9a). Under open-water conditions, total dissolved $\mathrm{CH}_{4}$ was 2-20 times greater in 2012 than in 2013. During all sampling dates, EVV Upper lake had the lowest $\mathrm{CH}_{4}$ inventory among the lakes (Fig. 9a).

Under open-water conditions, the inventories of both the stored and active pools of $\mathrm{CH}_{4}$ varied between lakes and years (Fig. 9b and c). In 2012, the majority ( $>50 \%$ ) of the total dissolved $\mathrm{CH}_{4}$ inventory in the water column of EVV Upper lake and Potentilla lake was associated with the hypolimnion (Fig. 9b). EVV Lower lake was the only lake in 2012 wherein the majority of the total inventory of $\mathrm{CH}_{4}$ occurred in the active pool of the epilimnion. In 2013, with the 
Table 4. Ranges of $\mathrm{CH}_{4}$ concentrations in profundal sediments and littoral sediment gas bubbles.

\begin{tabular}{lrr|rr}
\hline & \multicolumn{2}{c|}{ Profundal $(\mathrm{mM})$} & \multicolumn{2}{c}{ Littoral (ppmv) } \\
\cline { 2 - 5 } & Ice cover & Open water & Open water & Open water \\
& 2013 & 2013 & 2012 & 2013 \\
\hline EVV Upper lake & $0.7-1.9(6)$ & $0.3-0.7(5)$ & n.d. & $473000(1)$ \\
EVV Lower lake & $2.7(1)$ & $0.8-1.9(5)$ & n.d. & $332000(1)$ \\
Teardrop lake & n.d. & $0.5-1.2(5)$ & $378000(1)$ & $372000-404000(2)$ \\
Potentilla lake & $1.5-2.0(4)$ & $1.0-1.4(5)$ & $320000(1)$ & $166000-262000(2)$ \\
South Twin lake & $1.4-3.4(3)$ & $0.4-2.2(4)$ & $434000(1)$ & $228000-238000(2)$ \\
\hline
\end{tabular}

n.d. refers to seasons when a given lake was not measured. Sample size is in parentheses.
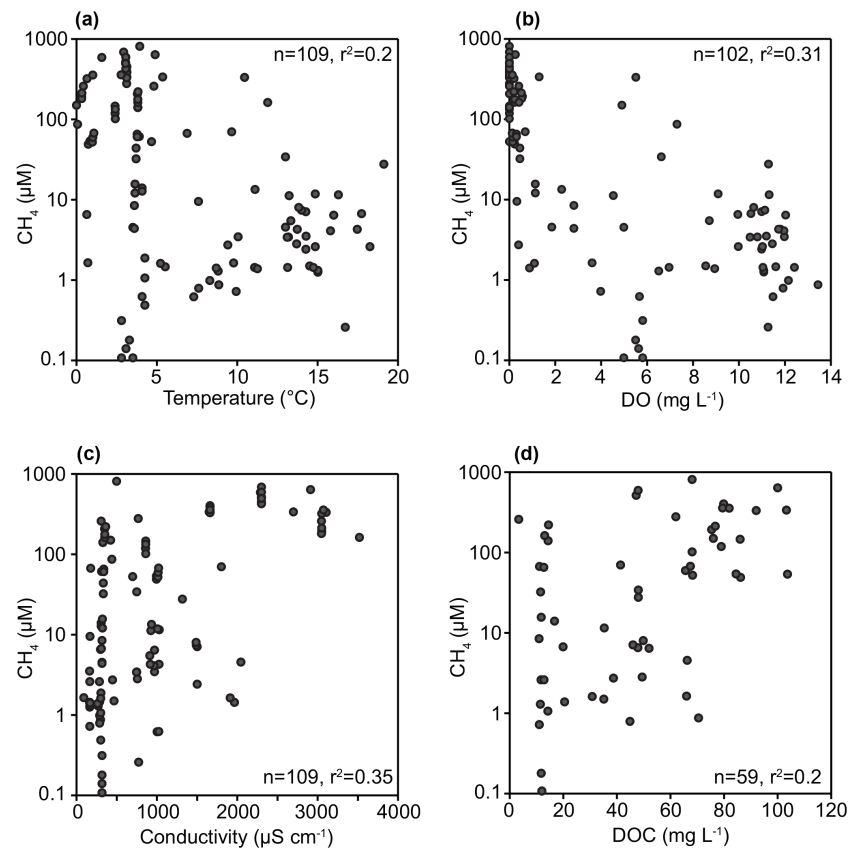

Figure 8. Relationships between dissolved $\mathrm{CH}_{4}$ concentrations from 2012 to 2014 and (a) temperature, (b) DO, (c) conductivity, and (d) DOC.

exception of EVV Upper lake, the majority of the total $\mathrm{CH}_{4}$ inventory was in the active pool in all of the lakes (Fig. 9c). EVV Upper lake was the only lake where the majority of the total $\mathrm{CH}_{4}$ inventory was associated with the hypolimnion (Fig. 9c). We saw no evidence of holes or moats in the ice in any of the lakes at the end of ice-covered conditions in 2013 or 2014, suggesting that the total inventories are likely relatively well conserved.

\subsubsection{Sediment $\mathrm{CH}_{4}$}

In all lakes, the concentrations of $\mathrm{CH}_{4}$ in porewaters of profundal sediments were an order of magnitude greater than dissolved $\mathrm{CH}_{4}$ concentrations in the water column (Table 4). Under ice cover in 2013, profundal $\mathrm{CH}_{4}$ concentra- tions were greater than under open-water conditions in 2013 for all of the lakes. Littoral sediment $\mathrm{CH}_{4}$ gas bubble concentrations in Potentilla and South Twin lake were greater in 2012 than 2013, whereas in Teardrop lake, concentrations of $\mathrm{CH}_{4}$ were greater in 2013 (Table 4). Overall, the maximum littoral sediment $\mathrm{CH}_{4}$ gas bubble concentration was 473000 ppmv in EVV Upper lake in 2013 and the minimum was 166000 ppmv in Potentilla 2013.

\section{Discussion}

\subsection{Spatial variation in aquatic chemistry and methane concentrations}

Aquatic chemistry of the study lakes during midsummer varied considerably among lakes with no discernable spatial trends. Chemical characteristics in each lake likely reflect interactions between basin-specific factors such as bedrock geology, basin morphometry, and macrophyte community composition. Geology in the Kangerlussuaq region has been generally described as dominated by granodioritic gneisses (Anderson et al., 2001; Jensen et al., 2002). Despite large differences in conductivity, $\mathrm{HCO}_{3}^{-}$was the dominant anion in the lakes. However, we have observed and measured sections of $\mathrm{SO}_{4}^{2-}$ minerals locally, occurring in orange-brown, thinly bedded outcrops interpreted as weathered, sulfide-rich metasediments (unpublished data). Elevated $\mathrm{SO}_{4}^{2-}$ in only EVV Upper lake leads us to suspect there is sulfide-rich, metasedimentary bedrock in the basin of this lake that has contributed to the anomalously high $\mathrm{SO}_{4}^{2-}$. In addition, pods of marble have been described in the region previously (Taylor and Kalsbeek, 1990), although they were not identified locally. These localized marble pods could be responsible for increased $\mathrm{Ca}^{2+}$ in Teardrop lake. Previous work in the Kangerlussuaq regions suggests that anomalously high concentrations of DOC may be associated with abundance of littoral macrophytes (Lim and Douglas, 2003; Lim et al., 2005; Anderson and Stedmon, 2007). The lowest DOC concentrations were from Potentilla lake, which had a comparatively lower density of macrophytes in comparison to the 
(a)


Figure 9. (a) Total inventory (moles) of $\mathrm{CH}_{4}$ in the water column of each lake under both open-water conditions in July 2012 (black) and July 2013 (grey) and ice-covered conditions in April 2013 (white) and April 2014 (hashed lines). For seasons where the inventory was low, total moles are written above the bars; n.d. refers to seasons when a given lake was not measured. (b, c) Relative pool sizes (\% of total) of dissolved $\mathrm{CH}_{4}$ under open-water conditions in July 2012 (b) and July 2013 (c). Pools are defined by redox conditions, where the stored pool (black) is the sum of $\mathrm{CH}_{4}$ from intervals where $\mathrm{DO}<1 \mathrm{mg} \mathrm{L}^{-1}$, gray represents the suboxic pool, and the active pool (white) is the sum of $\mathrm{CH}_{4}$ from well-mixed surface intervals potentially available for direct exchange with the atmosphere.

other lakes. The relative density of macrophyte communities in these hydrologically closed basins may strongly influence DOC concentrations in the lakes.

In the water column, $\mathrm{CH}_{4}$ concentrations are directly related to both conductivity and DOC, wherein high $\mathrm{CH}_{4}$ concentrations correspond with both high conductivity and DOC (Fig. 8). However, we do not find a direct relationship between maximum $\mathrm{CH}_{4}$ concentration and aquatic chemistry variables. Under open-water conditions of 2012, the maximum $\mathrm{CH}_{4}$ concentration in the water column was from the hypolimnion of South Twin lake. While South Twin lake did exhibit relatively high conductivity, DOC concentrations were relatively low. Similarly, the highest $\mathrm{CH}_{4}$ concentration was measured in Potentilla lake in 2013 under icecovered conditions, corresponding to the lowest conductivity and DOC measured in the study. The lowest concentrations of $\mathrm{CH}_{4}$ in all of the lakes were from epilimnetic waters, despite the wide range in aquatic chemistry lake to lake. In addition, EVV Upper lake had significantly higher concentrations of $\mathrm{SO}_{4}^{2-}$ than the other lakes in the study. Competition for substrates favors sulfate reduction (SR) and methanogenesis typically does not occur until $\mathrm{SO}_{4}^{2-}$ is exhausted and SR rates have decreased (Lovely and Klung, 1983, 1986;
Scholten et al., 2002; Ward and Winfrey, 1985). However, EVV Upper lake did not have the lowest concentrations of $\mathrm{CH}_{4}$ in the water column, suggesting there were sufficient reduced carbon substrates to fuel both SR and methanogenesis. Therefore, while aquatic chemistry in the water column could be a factor influencing $\mathrm{CH}_{4}$ production, at the level of this investigation, it alone is likely insufficient to explain the variation in $\mathrm{CH}_{4}$ concentrations observed lake to lake, as well as seasonally and annually.

\subsection{Effect of temperature on lake stratification}

Ground-level air temperatures strongly influence the thermal stratification of lakes during the open-water season. Warm ground-level air temperatures during open-water conditions in 2012 (Fig. 3) resulted in epilimnetic temperatures being $1.5-5^{\circ} \mathrm{C}$ higher in all of the study lakes relative to openwater conditions in 2013 (Fig. 4). Increased epilimnetic temperatures under open-water conditions in 2012 are consistent with both predictive models and measured temperatures indicating that warming climates result in higher epilimnetic temperatures (Honzo and Stefan, 1993; Fang and Stefan, 2009; Jankowski et al., 2006; Adrian et al., 2009; Coats et al., 2006). As a result of warmer epilimnetic waters, stronger 
thermal stratification occurred during open-water conditions in 2012 than in 2013, with $\Delta T \quad 4-9^{\circ} \mathrm{C}$ higher in 2012 (Fig. 4). In addition, wind speeds were significantly lower and air pressures were higher during open-water conditions in 2012 compared with 2013 (Fig. 3), leading to reduced mixing of the water column and greater heat transfer to shallower epilimnia. Temperature and thermal structure strongly influence DO concentrations in lakes, wherein stronger thermal stratification leads to increased anoxia in the hypolimnion (Hanson et al., 2006; Adrian et al., 2009; Foley et al., 2012). For example, the extremely warm European summer of 2003 resulted in stronger thermal stratification and hypolimnetic DO depletion in Swiss lakes (Jankowski et al., 2006). Similarly, as a result of strong thermal stratification in 2012, the hypolimnia of EVV Upper lake, EVV Lower lake, Potentilla, and South Twin lake were anoxic. For comparison, 1-34\% of water column in the lakes was anoxic in 2012, whereas the percentages decreased to $0-7 \%$ in 2013.

\subsection{Effects of temperature on $\mathrm{CH}_{4}$}

Ground-level air temperature differences result in warmer surface waters and increased stratification between 2012 and 2013, but a weak linear relationship is observed between water temperatures and dissolved $\mathrm{CH}_{4}$ concentrations (Fig. 8). Both the highest and lowest $\mathrm{CH}_{4}$ concentrations are observed in waters $<5^{\circ} \mathrm{C}$. In freshwater environments, the concentration of dissolved $\mathrm{CH}_{4}$ reflects the balance between $\mathrm{CH}_{4}$ production and $\mathrm{CH}_{4}$ consumption by anaerobic or aerobic oxidation (Duc et al., 2010; Dzyuban, 2010; Encinas Fernandez et al., 2014; Kankaala et al., 2007; Martinez-Cruz et al., 2015; Segarra et al., 2015; Smemo and Yavitt, 2011). Methane production is affected by temperature, where higher temperatures result in increased production (Duc et al., 2010). However, methanogenesis only occurs under anaerobic conditions (Borrel et al., 2011; Valentine et al., 1994; Yvon-Durocher et al., 2011). Under open-water conditions in all of the lakes, the majority of the water column is oxygenated (Fig. 5); therefore, production was likely minimal in the water column in both 2012 and 2013. Concentration of $\mathrm{CH}_{4}$ and DO are inversely related, wherein highest concentrations occur in anoxic waters and decrease with increasing DO (Fig. 8), suggesting $\mathrm{MOx}$ is driving the concentration of $\mathrm{CH}_{4}$ in the water column. However, consumption of $\mathrm{CH}_{4}$ by microbial methane oxidation is not strongly influenced by temperature (Duc et al., 2010) and has only been demonstrated to increase with increasing temperatures under $\mathrm{CH}_{4}$ saturated conditions (Lofton et al., 2013).

Despite the absence of a strong linear relationship between water temperature and $\mathrm{CH}_{4}$ concentrations, warmer groundlevel air temperatures correspond with increased $\mathrm{CH}_{4}$ both in the water column and the sediments in the study lakes at the time of sampling. Under open-water conditions, $\mathrm{CH}_{4}$ concentrations in the water column were significantly greater in 2012 than in 2013 (Fig. 8), corresponding with increased ground-level air temperatures. Similarly, under ice-covered conditions, ground-level air temperatures were $\sim 6{ }^{\circ} \mathrm{C}$ higher in 2013 than in 2014 and $\mathrm{CH}_{4}$ concentrations in the water column were greater for the two lakes in which there are data for both years (Fig. 9). The $\mathrm{CH}_{4}$ concentration differences occur throughout the water column, but are more pronounced in the bottom waters close to the sediment-water interface. It is possible that increased ground-level air temperatures result in increased production of $\mathrm{CH}_{4}$ in the profundal sediments, which lead to increased concentrations in the bottom waters of each lake. However, under open-water conditions in 2012, the bottom water temperatures were colder than in 2013, suggesting profundal sediments were not warmer due to increased ground-level air temperatures. More likely, the higher $\mathrm{CH}_{4}$ concentrations in the bottom waters during openwater conditions in 2012 were the result of increased thermal stratification and subsequent anoxia, allowing a buildup of $\mathrm{CH}_{4}$ in the bottom waters.

The concentrations of $\mathrm{CH}_{4}$ from profundal sediments during ice-covered conditions in 2013 were greater than from open-water conditions in 2013 (Table 4). While ground-level air temperatures were significantly colder during the 2013 ice-covered season compared to the 2013 open-water season (Fig. 3), the higher concentrations of $\mathrm{CH}_{4}$ during ice-covered conditions may be a relic of the anomalously warm conditions from the previous open-water conditions in 2012. In the littoral sediments, where there are data for consecutive years, gas bubble $\mathrm{CH}_{4}$ concentrations from 2012 were higher than in 2013 (Table 4), further suggesting that warmer groundlevel air temperatures result in increased $\mathrm{CH}_{4}$ production, consistent with experimental studies of methanogenesis response to higher temperature (Duc et al., 2010; Hoj et al., 2008; Lofton et al., 2013). However, it is important to note that littoral $\mathrm{CH}_{4}$ concentrations are an estimate, as a volume of sediment/sample was unmeasured. Therefore, it is possible that the increase in littoral $\mathrm{CH}_{4}$ concentrations is not the result of increased $\mathrm{CH}_{4}$ production, but of a different amount of sediment disturbed.

Without temperature data for profundal and littoral sediments, it is impossible to directly determine whether warmer temperatures result in an increase in $\mathrm{CH}_{4}$ production or whether other factors may influence production of $\mathrm{CH}_{4}$. However, because bottom water temperatures were colder during open-water conditions in 2012 than in 2013 (Fig. 4), it is unlikely that profundal sediments were warmer in response to warmer ground-level air temperatures. In addition to temperature, methanogenesis is also influenced by the amount and quality of organic carbon substrates (Borrel et al., 2011; West et al., 2012). Lakes in this study are all embedded within continuous permafrost, with an active layer $<0.5 \mathrm{~m}$ thick. It is possible that the anomalously warm conditions in 2012 resulted in warming and thickening of the active permafrost layer, which could have caused organic carbon, nutrients, and ions to enter the lakes and be available for microbial utilization (Adrian et al., 2009; Kokelj et 
al., 2009; Lougheed et al., 2011; Weyhenmeyer and Karlsson, 2009). However, under open-water conditions, DOC was only higher in one lake in 2012 compared to 2013 and DOC concentrations during ice-covered conditions in 2013 and 2014 were similar (Table 2). Significantly higher specific conductivity during open-water conditions in 2012 compared to 2013 was observed for all of the lakes (Table 2), which could be attributed to an additional source from permafrost thaw. Increases in DOC and conductivity were observed in thaw ponds in western Siberia during the anomalous hot summer of 2012, but these were attributed to evapoconcentration effects (Pokrovsky et al., 2013). In the Greenlandic lakes, significant water level changes between the two consecutive years of this study were not observed, so it is unlikely that the higher conductivity in 2012 was the result of evaporation.

\subsection{Effects of stratification on $\mathrm{CH}_{4}$}

Enhanced thermal stratification and anoxia during openwater conditions in 2012 corresponded with significantly higher $\mathrm{CH}_{4}$ concentrations in the water column. The most notable difference in $\mathrm{CH}_{4}$ concentrations between 2012 and 2013 occurred within the bottom waters, which were anoxic in 2012. Under open-water conditions in 2012, the amount of $\mathrm{CH}_{4}$ stored in the hypolimnion was 2 to 300 times higher than in 2013. The higher $\mathrm{CH}_{4}$ concentrations may be the result of increased $\mathrm{CH}_{4}$ production due to more extensive anaerobic conditions. However, the higher $\mathrm{CH}_{4}$ concentrations were more likely the result of larger pools of anoxic waters in 2012 allowing for a buildup of $\mathrm{CH}_{4}$ that corresponded in increased $\mathrm{CH}_{4}$ storage in the water column (Fig. 8). During fall overturn, the storage pool of $\mathrm{CH}_{4}$ is susceptible to diffusion and/or oxidation (Encinas Fernandez et al., 2014; Kankaala et al., 2007; López Bellido et al., 2009). If half of the stored $\mathrm{CH}_{4}$ is emitted during fall overturn, as suggested by results from Fernandez et al. (2014), the fall overturn $\mathrm{CH}_{4}$ flux would be significantly larger in 2012 than that in 2013 as a result of the more extensive anoxia in 2012.

Weaker thermal stratification during open-water conditions in 2013 meant that $93-100 \%$ of the water column in the lakes had DO concentrations $>1 \mathrm{mg} \mathrm{L}^{-1}$. When $\mathrm{CH}_{4}$ diffusing from anoxic sediments reaches oxic sediment or water, the majority of it is oxidized (Bastviken et al., 2002; Dzyuban, 2010; Kankaala et al., 2007). MOx is highly efficient at consuming $\mathrm{CH}_{4}$, thereby lowering $\mathrm{CH}_{4}$ concentrations. The percentage of $\mathrm{CH}_{4}$ oxidized can be estimated by assuming that $\mathrm{CH}_{4}$ at the water-air interface originates from diffusion through the water column from the profundal sediments. Given that an increased proportion of the water column was oxic under open-water conditions 2013, we initially hypothesized that the percentage of $\mathrm{CH}_{4}$ oxidized would be greater in 2013 than in 2012. However, under openwater conditions in 2013, the percentage of $\mathrm{CH}_{4}$ oxidized was similar to, or less than, in 2012. Consistent with $\mathrm{CH}_{4}$ oxidation rates from Alaskan lakes, MOx controls $\mathrm{CH}_{4}$ concentrations when DO is present (Martinez-Cruz et al., 2015). Under warm conditions in 2012, not only were $\mathrm{CH}_{4}$ concentrations in sediments and anoxic waters elevated but the percentage of $\mathrm{CH}_{4}$ oxidized was also higher. Several studies suggest that $\mathrm{MOx}$ is important for mitigating $\mathrm{CH}_{4}$ emissions to the atmosphere (Martinez-Cruz et al., 2015; Milucka et al., 2015; Segarra et al., 2015). However, despite the likelihood that MOx was more efficient in 2012 under warmer conditions, $\mathrm{CH}_{4}$ concentrations in the stored pool were higher in 2012 than in 2013.

While significant variations in $\mathrm{CH}_{4}$ concentrations and inventories were observed under between the consecutive years under open-water conditions, the amount of $\mathrm{CH}_{4}$ stored under ice cover was significantly greater than that stored in the anoxic hypolimnion under open-water conditions (Figs. 36). For South Twin lake, the $\mathrm{CH}_{4}$ storage under ice cover in 2013 was more than an order of magnitude greater than that stored in the hypolimnion during open-water conditions in 2012, and in EVV Lower lake it was two orders of magnitude greater (Figs. 3-6). In these small Greenlandic lakes, emissions during spring overturn currently reflect the largest potential flux of $\mathrm{CH}_{4}$ to the atmosphere. Similarly, in other Arctic lakes, $\mathrm{CH}_{4}$ emissions during spring overturn after ice breakup are usually larger than $\mathrm{CH}_{4}$ emissions during fall overturns (Juutinen et al., 2009; López Bellido et al., 2009; Karlsson et al., 2013; Miettinen et al., 2015).

\subsection{Implications for a warmer Arctic}

In the Arctic, lakes are ice-covered for more than 8 months of the year (Belzile et al., 2001). The study lakes here are ice-covered $\sim 10$ months of the year. At sampling under icecovered conditions, lakes have been covered $\sim 8$ months. In each of the study lakes, $\mathrm{CH}_{4}$ concentrations are significantly higher under ice-covered conditions compared to open-water conditions (Fig. 7), which is also observed in other northern latitude lakes that are ice-covered the majority of the year (Juutinen et al., 2009; Martinez-Cruz et al., 2015). Ice cover impedes gas exchange between the water and the atmosphere, promoting buildup of $\mathrm{CH}_{4}$ in the water column leading to increased $\mathrm{CH}_{4}$ storage (Bastviken et al., 2004; Juutinen et al., 2009; Martinez-Cruz et al., 2015; Phelps et al., 1998). No holes or moats were observed in the ice cover during sampling; therefore, the total inventory of $\mathrm{CH}_{4}$ in the water column under ice-covered conditions was stored. Similar to stored $\mathrm{CH}_{4}$ during stratification in open-water conditions, $\mathrm{CH}_{4}$ stored under ice is susceptible to emission to the atmosphere during spring overturns during and after ice breakup.

Projected climate change is expected to change ice cover characteristics in lakes (Fang and Stefan, 2009; Mueller et al., 2009). Ice coverage duration has already decreased for many lakes as ground-level air temperatures have increased (Bertilsson et al., 2013; Weyhenmeyer et al., 2011). As perennially ice-covered lakes begin to develop open-water 
periods for at least some portions of the year, the number of seasonally frozen lakes will increase (Mueller et al., 2009). Currently, the largest efflux of $\mathrm{CH}_{4}$ from our study lakes will most likely occur during ice breakup and spring overturn, consistent with other Arctic lakes (Karlsson et al., 2013; Miettinen et al., 2015). Changes in the duration of seasonal ice cover will result in changes in inventories of under-ice $\mathrm{CH}_{4}$. We predict that, as the duration of ice cover decreases, the amount of $\mathrm{CH}_{4}$ stored under ice cover will likely decrease due to the shorter time for accumulation. If the amount of stored $\mathrm{CH}_{4}$ under ice cover decreases, this will potentially reduce the amount of $\mathrm{CH}_{4}$ emitted during ice breakup and spring overturn.

In addition to a decrease in ice cover, our results also suggest that an increase in ground-level air temperatures will result in enhanced thermal stability and anoxia in Arctic lakes, as we observed during open-water conditions in 2012. The duration of open-water thermal stratification will also likely increase in concert with the decrease in ice cover. The combined effects of extended season and greater strength of stratification are likely to be development of higher $\mathrm{CH}_{4}$ inventories in the water column during open-water periods. Conceptually, as anoxic zones expand in space and duration, the influence of methanogenic sediments on water column inventories of methane should increase. Currently, small lakes emit substantially more $\mathrm{CH}_{4}$ per unit area than larger lakes during open-water conditions (Bastviken et al., 2004; Cole et al., 2007; Juutinen et al., 2009). Small, shallow likes are more susceptible to thermal change due to increased ground-level air temperatures and will likely continue to be major $\mathrm{CH}_{4}$ contributors to the atmosphere. In fact, our results suggest that increased warming in the Arctic will result in greater summer inventories of $\mathrm{CH}_{4}$ and consequently larger emissions of $\mathrm{CH}_{4}$ to the atmosphere during fall overturn in small lakes.

\section{Conclusions}

Over the past half century, the Arctic has warmed at a rate greater than the global average, and climate models predict further polar amplification, with the Arctic continuing to warm at a faster rate than other regions. The anomalously warm summer of 2012 in Greenland corresponded with significantly higher $\mathrm{CH}_{4}$ concentrations under open-water conditions in a series of small lakes compared to the following year. Stronger thermal stratification under warmer conditions lead to increased $\mathrm{CH}_{4}$ storage in the lakes. With impending warming climate, increased stratification and $\mathrm{CH}_{4}$ storage in lakes will likely lead to greater potential fluxes during fall overturn. Currently, in these small, seasonally icecovered Arctic lakes, the greatest concentrations of $\mathrm{CH}_{4}$ in the water column are occurring under ice-covered conditions. Changes in seasonal ice cover will result in changes in under ice $\mathrm{CH}_{4}$ inventories, and consequently lead to reductions in the amount of $\mathrm{CH}_{4}$ emitted during ice breakup and spring overturn. These results suggest that interannual variation in ground-level air temperatures may be the primary driver of changes in methane dynamics because it controls both the strength of thermal stratification and duration of ice cover. We predict that as the climate continues to warm, the greatest annual efflux of $\mathrm{CH}_{4}$ from small Arctic lakes will shift from spring overturn to fall overturn.

\section{Data availability}

Data are available and can be requested by contacting the corresponding author (sbcadieux@gmail.com).

Competing interests. The authors declare that they have no conflict of interest.

Acknowledgements. Funding for this work was provided by NASA ASTEP grant \#NNX11AJ01G. We thank Contour Innovations LLC for assistance with bathymetric maps and Amy Goldman, Seth Young, and Yongbo Peng for assistance in the field with sample collection. For logistical support, we thank Polar Field Services, Inc., Kangerlussuaq International Science Support, and Ruth Droppo for logistical support. Weather data from the Programme for Monitoring of the Greenland Ice Sheet (PROMICE) and the Greenland Analogue Project (GAP) were provided by the Geological Survey of Denmark and Greenland (GEUS) at http://www.promice.dk.

Edited by: G. Abril

Reviewed by: two anonymous referees

\section{References}

Adrian, R., O’Reilly, C. M., Zagarese, H., Baines, S. B., Hessen, D. O., Keller, W., Livingstone, D. M., Sommaruga, R., Straile, D., Van Donk, E., Weyhenmeyer, G. A., and Winder, M.: Lakes as sentinels of climate change, Limnol. Oceanogr., 54, 2283-2297, 2009.

Anderson, N. J., Harriman, R., Ryves, D. B., and Patrick, S. T.: Dominant factors controlling variability in the ionic composition of West Greenland lakes, Arct. Antarct. Alp. Res., 33, 418-425, 2001.

Anderson, N. J. and Stedmon, C. A.: The effect of evapoconcentration on dissolved organic carbon concentration and quality in lakes of SW Greenland, Freshwater Biol., 52, 280-289, 2007.

Bastviken, D., Ejlertsson, J., and Tranvik, L.: Measurement of methane oxidation in lakes: a comparison of methods, Environ. Sci. Technol., 36, 3354-3361, 2002.

Bastviken, D., Cole, J., Pace, M., and Tranvik, L.: Methane emissions from lakes: Dependence of lake characteristics, two regional assessments, and a global estimate, Global Biogeochem. Cy., 18, GB4009, doi:10.1029/2004GB002238, 2004. 
Bastviken, D., Tranvik, L., Downing, J. A., Crill, P. M., and EnrichPrast, A.: Freshwater methane emissions offset the continental carbon sink, Science, 331, doi:10.1126/science.1196808, 2011.

Belzile, C., Vincent, W. F., Gibson, J. A. E., and Hove, P. V.: Biooptical characteristics of the snow, ice, and water column of a perennially ice-covered lake in the High Arctic, Can. J. Fish. Aquat. Sci., 58, 2405-2418, 2001.

Bertilsson, S., Burgin, A., Carey, C. C., Fey, S. B., Grossart, H.-P., Grubisic, L. M., Jones, I. D., Kirillin, G., Lennon, J. T., Shade, A., and Smyth, R. L.: The under-ice microbiome of seasonally frozen lakes, Limnol. Oceanogr., 58, 1998-2012, 2013.

Borrel, G., Jezequel, D., Biderre-Petit, C., Morel-Desrosiers, N., Morel, J. P., Peyret, P., Fonty, G., and Lehours, A. C.: Production and consumption of methane in freshwater lake ecosystems, Res. Microbiol., 162, 832-847, 2011.

Butcher, J. B., Nover, D., Johnson, T. E., and Clark, C. M.: Sensitivity of lake thermal and mixing dynamics to climate change, Climatic Change, 129, 295-305, 2015.

Cadieux, S. B., White, J. R., Sauer, P. E., Peng, Y., Goldman, A. E., and Pratt, L. M.: Large fractionations of $\mathrm{C}$ and $\mathrm{H}$ isotopes related to methane oxidation in Arctic lakes, Geochim. Cosmochim. Ac., 187, 141-155, 2016.

Coats, R., Perez-Losada, J., Schladow, G., Richards, R., and Goldman, C.: The warming of Lake Tahoe, Climatic Change, 76, 121148, 2006.

Cole, J., Prairie, Y. T., Caraco, N. F., McDowell, W. H., Tranvik, L., Striegl, R. G., Duarte, C. M., Kortelainen, P., Downing, J. A., Middleburg, J. J., and Melack, J.: Plumbing the global carbon cycle: Integrating inland waters into the terrestrial carbon budget, Ecosystems, 10, 171-184, 2007.

Downing, J. A.: Emerging global role of small lakes and ponds: little things mean a lot, Limnetica, 29, 9-24, 2010.

Downing, J. A., Prairie, Y. T., Cole, J., Duarte, C. M., Tranvik, L. J., Strigel, R. G., McDowell, W. H., Kortelainen, P., Caracao, N. F., Melack, J. M., and Middelburg, J. J.: The global abundance and size distribution of lakes, ponds, and impoundments, Limnol. Oceanogr., 51, 2388-2397, 2006.

Driscoll, C. T. and Newton, R. M.: Chemical Characteristics of Adirondack Lakes, Environ. Sci. Technol., 19, 1018-1024, 1985.

Duc, N. T., Crill, P., and Bastviken, D.: Implications of temperature and sediment characteristics on methane formation and oxidation in lake sediments, Biogeochemistry, 100, 185-196, 2010.

Dzyuban, A. N.: Dynamics of microbial oxidation of methane in the water of stratified lakes, Microbiology, 79, 822-829, 2010.

Encinas Fernandez, J., Peeters, F., and Hofmann, H.: Importance of the autumn overturn and anoxic conditions in the hypolimnion for the annual methane emissions from a temperate lake, Environ. Sci. Technol., 48, 7297-7304, 2014.

Fang, X. and Stefan, H. G.: Simulations of climate effects on water temperature, dissolved oxygen, and ice and snow covers in lakes of the contiguous Unitied States under past and future climate scenarios, Limnol. Oceanogr., 54, 2359-3270, 2009.

Foley, B., Jones, I. D., Maberly, S. C., and Rippey, B.: Long-term changes in oxygen depletion in a small temperate lake: effects of climate change and eutrophication, Freshwater Biol., 57, 278289, doi:10.1111/j.1365-2427.2011.02662.x, 2012.

Frenzel, P., Thebrath, B., and Conrad, R.: Oxidation of methane in the oxic surface layer of a deep lake sediment (Lake Constance), FEMS Microbiol. Ecol., 73, 149-158, 1990.
Fuchs, A., Lyautey, E., Motuelle, B., and Casper, P.: Effects of increasing temperatures on methane concentrations and methanogenesis during experimental incubation of sediments from oligoand mesotrophic lakes, J. Geophys. Res.-Biogeo., 121, 13941406, doi:10.1002/2016JG003328, 2016.

Goldman, A. E., Cadieux, S. B., White, J. R., and Pratt, L. M.: Passive sampling method for high-resolution concentration and isotopic composition of dissolved methane in Arctic Lakes, Limnol. Oceanogr.-Meth., 14, 69-78, 2016.

Greene, S., Walter Anthony, K. M., Archer, D., Sepulveda-Jauregui, A., and Martinez-Cruz, K.: Modeling the impediment of methane ebullition bubbles by seasonal lake ice, Biogeosciences, 11, 6791-6811, doi:10.5194/bg-11-6791-2014, 2014.

Hall, D. K., Comiso, J. C., DiGirolamo, N. E., Shuman, C. A., Box, J. E., and Koenig, L. S.: Variability in the surface temperature and melt extent of the Greenland ice sheet from MODIS, Geophys. Res. Lett., 40, 2114-2120, 2013.

Hanna, E., Jones, J. M., Cappelen, J., Mernild, S. H., Wood, L., Steffen, K., and Huybrechts, P.: The influence of North Atlantic atmospheric and oceanic forcing effects on 1900-2010 Greenland summer climate and ice melt/runoff, Int. J. Climatol., 33, 862-880, 2013.

Hanna, E., Fettweis, X., Mernild, S. H., Cappelen, J., Ribergaard, M. H., Shuman, C. A., Steffen, K., Wood, L., and Mote, T. L.: Atmospheric and oceanic climate forcing of the exceptional Greenland ice sheet surface melt in summer 2012, Int. J. Climatol., 34, 1022-1037, 2014.

Hanson, P. C., Carpenter, S. R., Armstrong, D. E., Stanley, E. H., and Kratz, T. K.: Lake dissolved inorganic carbon and dissolved oxygen: changing drivers from days to decades, Ecol. Monogr., 76, 343-363, doi:10.1890/00129615(2006)076[0343:LDICAD]2.0.CO;2, 2006.

Hinkel, K. M., Lenters, J. D., Sheng, Y., Lyons, E. A., Beck, R. A., Eisner, W. R., Mauer, E. F., Wang, J., and Potter, B. L.: Thermokarst lakes on the Arctic Coastal Plain of Alaska: Spatial and temporal variability in summer water temperature, Permafrost Periglac., 23, 207-217, 2012.

Hoj, L., Olsen, R. A., and Torsvik, V. L.,: Effects of temperature on the diversity and community structure of known methanogenic groups and other archaea in high Arctic peat, ISME J., 2, 37-48, 2008.

Hondzo, M. and Stefan, H. G.: Regional water temperature characteristics of lakes subjected to climate change, Climatic Change, 24, 187-211, 1993.

IPCC: Summary for Policymakers, in: Climate Change 2013: The Physical Science Basics, edited by: Stocker, T. F., Quin, D., Plattner, G. K., Tignor, M., Allen, S. K., Boschung, J., and Nauels, A., Contribution of Working Group I to the Fifth Assessment Report on the Intergovernmental Panel on Climate Change, Cambridge University Press, Cambride, United Kingdom, New York, NY, USA, 2013.

Jammet, M., Crill, P., Dengel, S., and Friborg, T.: Large methane emissions from a subarctic lake during spring thaw: Mechanisms and landscape significance, J. Geophys. Res.-Biogeo., 120, 2289-2305, doi:10.1002/2015JG003137, 2015.

Jankowski, T., Livingstone, D. M., Buhrer, H., Forster, R., and Niederhauser, P.L Consequences of the 2003 European heat wave for lake temperature profiles, thermal stability, and hypolim- 
netic oxygen depletion: Implications for a warmer world, Limnol. Oceanogr., 51, 815-819, 2006.

Jensen, S. M., Hansen, H., Secher, K., Steenfelt, A., Schjoth, F., and Rasmussen, T.: Kimberlites and other ultramafic alkaline rocks in the Sisimiut-Kangerlussuaq region, southern West Greenland, Geol. Greenland Survey Bull., 191, 57-66, 2002.

Jorgensen, A. S. and Andreasen, F.: Mapping of permafrost surface using ground-penetrating radar at Kangerlussuaq Airport, western Greenland, Cold Reg. Sci. Technol. 48, 64-72, 2007.

Juutinen, S., Rantakari, M., Kortelainen, P., Huttunen, J. T., Larmola, T., Alm, J., Silvola, J., and Martikainen, P. J.: Methane dynamics in different boreal lake types, Biogeosciences, 6, 209223, doi:10.5194/bg-6-209-2009, 2009.

Kankaala, P., Huotari, J., Peltomaa, E., Saloranta, T., and Ojala, A.: Methanotrophic activity in relation to methane efflux and total heterotrophic bacterial production in a stratified, humic, boreal lake, Limnol. Oceanogr., 51, 1195-1204, 2006.

Kankaala, P., Taipale, S., Nykänen, H., and Jones, R. I.: Oxidation, efflux, and isotopic fractionation of methane during autumnal turnover in a polyhumic, boreal lake, J. Geophys. Res., 112, G02033, doi:10.1029/2006JG000336, 2007.

Karlsson, J., Giesler, R., Persson, J., and Lundin, E.: High emission of carbon dioxide and methane during ice thaw in high latitude lakes, J. Geophys. Res. Lett., 40, 1-5, doi:10.1002/grl.50152, 2013

Keppler, F., Hamilton, J. T., Brass, M., and Rockmann, T.: Methane emissions from terrestrial plants under aerobic conditions, Nature, 439, 187-191, 2006.

Kokelj, S. V., Zajdlik, B., and Thompson, M. S.: The impacts of thawing permafrost on the chemistry of lakes across the subarctic boreal-tundra transition, Mackenzie Delta region, Canada, Permafrost Periglac., 20, 185-199, 2009.

Kraemer, B. M., Hook, S., Huttula, T., Kotilainen, P., O’Reilly, C. M., Peltonen, A., Plisnier, P.-D., Sarvala, J., Tamatamah, R., Vadeboncoeur, Y., Wehril, B., and McIntyre, P. B.: Century-Long Warming Trends in the Upper Water Column of Lake Tanganyika, PLoS One, 10, e0132490, doi:10.1371/journal.pone.0134537, 2015.

Lide, D. R. and Fredrikse, H. P. R.: CRC handbook of chemistry and physics, 76 Edn. CRC Press, Boca Raton, FL, 1995.

Liikanen, A., Huttunen, J. T., Murtoniemi, T., Tanskanene, H., Vaisanen, T., Silvola, J., Alm, J., and Marktikainen, P. J.: Spatial and seasonal variation in greenhouse and nutrient dynamics and their interactions in the sediment of a boreal eutrophic lake, Biogeochemistry, 65, 83-103, 2003.

Lim, D. and Douglas, M. S. V.: Limnological characteristics of 22 lakes and ponds in the Haughton Crater Region of Devon Island, Nunavut, Canadian High Arctic, Arct. Antarct. Alp. Res., 35, 509-519, 2003.

Lim, D., Douglas, M. S. V., and Smol, J. P.: Limnology of 46 lakes and ponds on Banks Island, N.W.T., Canadian Arctic Archipelago, Hydrobiologia, 545, 11-32, 2005.

Livingstone, D. M.: Impact of secular climate change on the thermal structure of a large temperate central European lake, Climatic Change, 57, 205-225, 2003.

Lofton, D. D., Whalen, S. C., and Hershey, A. E. Effect of temperature on methane dynamics and evaluation of methane oxidation kinetics in shallow Arctic Alaskan lakes, Hydrobiologia, 721, 209-222, 2013.
López Bellido, J., Tulonen, T., Kankaala, P., and Ojala, A.: $\mathrm{CO}_{2}$ and $\mathrm{CH}_{4}$ fluxes during spring and autumn mixing periods in a boreal lake (Pääjärvi, southern Finland), J. Geophys. Res., 114, G04007, doi:10.1029/2009JG000923, 2009.

Lougheed, V. L., Butler, M. G., McEwen, D. C., and Hobbie, J. E.: Changes in Tundra Pond Limnology: Re-sampling Alaskan Ponds After 40 Years, Ambio, 40, 589-599, 2011.

Lovely, D. R. and Klung, M. J.: Sulfate reducers can out-compete methanogens at fresh-water sulfate concentrations, Appl. Environ. Microb., 45, 187-192, 1983.

Lovely, D. R. and Klung, M. J.: Model for the distribution of sulfate reduction and methanogenesis in freshwater sediments, Geochim. Cosmochim. Ac., 50, 11-18, 1986.

MacIntyre, S., Fram, J. P., Kushner, P. J., Bettez, N. D., O’Brien, J. O., Hobbie, J. E., and Kling, G. W.: Climate-related variations in mixing dynamics in an Alaskan arctic lake, Limnol. Oceanogr., 54, 2401-2417, 2009.

Martinez-Cruz, K., Sepulveda-Jauregui, A., Walter Anthony, K., and Thalasso, F.: Geographic and seasonal variation of dissolved methane and aerobic methane oxidation in Alaskan lakes, Biogeosciences, 12, 4595-4606, doi:10.5194/bg-12-4595-2015, 2015.

Michmerhuizen, C. M., Striegl, R. G., and McDonald, M. E.: Potential methane emission from north-temperate lakes following ice melt, Limnol. Oceanogr., 41, 985-991, 1996.

Miettinen, H., Pumpanen, J., Heiskanen, J. J., Aaltonen, H., Mammarella, I., Ojala, A., Levula, J., and Rantakari, M.: Towards a more comprehensive understanding of lacustrine greenhouse gas dynamics two-year measurements of concentrations and fluxes of $\mathrm{CO}_{2}, \mathrm{CH}_{4}$ and $\mathrm{N}_{2} \mathrm{O}$ in a typical boreal lake surrounded by managed forests, Boreal Environ. Res. 20, 75-89, 2015.

Milucka, J., Kirf, M., Lu, L., Krupke, A., Lam, P., Littmann, S., Kuypers, M. M. M., and Schubert, C.: Methane oxidation coupled to oxygenic photosynthesis in anoxic waters, ISME J., 9, 1991-2002, doi:10.1038/ismej.2015.12, 2015.

Mueller, D. R., Van Hove, P., Antoniades, D., Jeffries, M. O., and Vincent, W. F.: High Arctic lakes as sentinel ecoystems: Cascading regime shifts in climate, ice cover, and mixing, Limnol. Oceanogr., 54, 2371-2385, 2009.

Nghiem, S. V., Hall, D. K., Mote, T. L., Tedesco, M., Albert, M. R., Keegan, K., Shuman, C. A., DiGirolamo, N. E., and Neumann, G.: The extreme melt across the Greenland ice sheet in 2012, Geophys. Res. Lett., 39, L20502, doi:10.1029/2012GL053611, 2012.

Nisbet, R. E., Fisher, R., Nimmo, R. H., Bendall, D. S., Crill, P. M., Gallego-Sala, A. V., Hornibrooke, E. R. C., Lopez-Juez, E., Lowry, D., Nisbet, P. B. R., Shuckburger, E. F., Sriskantharajah, S., Howe, C. J., and Nisbet, E. G.: Emission of methane from plants, Proc. Biol. Sci., 276, 1347-1354, 2009.

Oviedo-Vargas, D., Royer, T. V., and Johnson, L. T.: Dissolved organic carbon manipulation reveals coupled cycling of carbon, nitrogen, and phosphorus in a nitrogen-rich stream, Limnol. Oceanogr., 58, 1196-1206, 2013.

Phelps, A. R., Peterson, K. M., and Jeffries, M. O.: Methane efflux from high-latitude lakes during spring ice melt, J. Geophys. Res., 103, 29029-29036, 1998.

Pokrovsky, O. S., Shirokova, L. S., Kirpotin, S. N., Kulizhsky, S. P., and Vorobiev, S. N.: Impact of western Siberia heat wave 2012 on greenhouse gases and trace metal concentration in thaw lakes of 
discontinuous permafrost zone, Biogeosciences, 10, 5349-5365, doi:10.5194/bg-10-5349-2013, 2013.

Rasilo, T., Prairie, Y. T., and Del Giorgio, P. A.: Large-scale patterns in summer diffusive $\mathrm{CH}_{4}$ fluxes across boreal lakes, and contribution to diffusive $\mathrm{C}$ emissions, Glob. Change Biol., 21, 1124-1139, 2015.

Scholten, J. C. M., van Bodegom, P. M., Vogelaar, J., van Ittersum, A., Hordijk, R., Roelofsen, W., and Stams, A. J.: Effect of sulfate and nitrate on acetate conversion by anaerobic microorganisms in a freshwater sediment, FEMS Microbiol. Ecol., 42, 375-385, 2002.

Segarra, K. E., Schubotz, F., Samarkin, V., Yoshinaga, M. Y., Hinrichs, K. U., and Joye, S. B.: High rates of anaerobic methane oxidation in freshwater wetlands reduce potential atmospheric methane emissions, Nat. Commun., 6, 7477, doi:10.1038/ncomms8477, 2015.

Sepulveda-Jauregui, A., Walter Anthony, K. M., Martinez-Cruz, K., Greene, S., and Thalasso, F.: Methane and carbon dioxide emissions from 40 lakes along a north-south latitudinal transect in Alaska, Biogeosciences, 12, 3197-3223, doi:10.5194/bg-123197-2015, 2015.

Smemo, K. A. and Yavitt, J. B.: Anaerobic oxidation of methane: an underappreciated aspect of methane cycling in peatland ecosystems?, Biogeosciences, 8, 779-793, doi:10.5194/bg-8-779-2011, 2011.

Stewart, R. E. and Kantrud, H. A.: Classification of natural ponds and lakes in the glaciated prairie region, in: Service, U.S. Bur. Sport Fish. Wildl., Res. Publ. 92., Resource Publication, Washington, D.C., 1971 .

Tan, Z. and Zhuang, Q.: Arctic lakes are continuous methane sources to the atmosphere under warming conditions, Environ. Res. Lett., 10, 054016, doi:10.1088/1748-9326/10/5/054016, 2015a.

Tan, Z. and Zhang, Q.: Methane emissions from pan-Arctic lakes during the 21st century: An analysis with process-based models of lake evolution and biogeochemistry, J. Geophys. Res.-Biogeo., 120, 2641-2653, doi:10.1002/2015JG003184, 2015b.

Tan, Z., Zhuang, Q., and Water Anthony, K.: Modeling methane emissions from arctic lakes: Model development and site-level study, J. Adv. Model. Earth Syst., 7, 459-483, doi:10.1002/2014MS000344, 2015.

Taylor, P. N. and Kalsbeek, F.: Dating the metamorphism of Precambrian marbles: 760 Examples from Proterozoic mobile belts in Greenland, Chemical Geology: Isotope, 761, Geoscience Section, 86, 21-28, 1990.

Valentine, D. W., Holland, E. A., and Schimel, D. S.: Ecosystem and physiological controls over methane production in northern wetlands, J. Geophys. Res., 99, 1563-1571, 1994.

van As, D., Fausto, R. S., Ahlström, A. P., Andersen, S. B., Andersen, M. L., Citterio, M., Edelvang, K., Gravesen, P., Machguth, H., Nick, F. M., Nielsen, S., and Weidick, A.: Programme for Monitoring of the Greenland Ice Sheet (PROMICE): first temperature and ablation record, Geological. Geol. Surv. Den Greenl., 23, 73-76, 2011.

van As, D., Hubbard, A. L., Hasholt, B., Mikkelsen, A. B., van den Broeke, M. R., and Fausto, R. S.: Large surface meltwater discharge from the Kangerlussuaq sector of the Greenland ice sheet during the record-warm year 2010 explained by de- tailed energy balance observations, The Cryosphere, 6, 199-209, doi:10.5194/tc-6-199-2012, 2012.

Van Tatenhove, F. G. M. and Olesen, O.B.: Ground temperature and related permafrost characteristics in west Greenland, Permafrost Periglac., 5, 199-215, 1994.

Walter, K. M., Zimov, S. A., Chanton, J. P., Verbyla, D., and Chapin III, F. S.: Methane bubbling from Siberian thaw lakes as a positive feedback to climate warming, Nature, 443, 71-75, 2006.

Walter, K. M., Smith, L. C., and Chapin III, F. S.: Methane bubbling from northern lakes: present and future contributions to the global methane budget, Philos. T. Roy. Soc. A, 365, 1657-1676, 2007.

Walter Anthony, K. M., Anthony, P., Grosse, G., and Chanton, J.: Geologic methane seeps along boundaries of Arctic permafrost thaw and melting glaciers, Nat. Geosci., 5, 419-426, 2012.

Ward, D. M. and Winfrey, M. R.: Interactions between methanogenic and sulfate-reducing bacteria in sediments, Adv. Aq. Microbiol., 3, 141-179, 1985.

Webster, K. D., White, J. R., and Pratt, L. M.: Ground-level concentrations of atmospheric methane in southwest Greenland evaluated using open-path laser spectrocopy and cavity-enhanced absoprtion spectroscopy, Arct. Antarct. Alp. Res., 47, 599-609, 2015.

West, W. E., Coloso, J. J., and Jones, S. E.: Effects of algal and terrestrial carbon on methane production rates and methanogen community structure in a temperate lake sediment, Freshwater Biol., 57, 949-955, 2012.

Westendorp, R. G.: A quantitation method for dynamic headspace analysis using multiple runs, J. Chromatogr. Sci., 23, 521-524, 1985.

Weyhenmeyer, G. A. and Karlsson, J: Nonlinear response of dissolved organic carbon concentrations in boreal lakes to increasing temperatures, Limnol. Oceanogr., 54, 2513-2519, 2009.

Weyhenmeyer, G. A., Livingstone, D. M., Meili, M., Jensen, O., Benson, B., and Magnuson, J. J.: Large geographical differences in the sensitivity of ice-covered lakes and rivers in the Northern Hemisphere to temperature changes, Glob. Change Biol., 117, 268-275, 2011.

Wik, M., Crill, P. M., Varner, R. K., and Bastviken, D.: Multiyear measurements of ebullitive methane flux from three subarctic lakes, J. Geophys. Res. 18, 1307-1321, 2013.

Wik, M., Varner, R. K., Walter Anthony, K., MacIntyre, S., and Bastviken, D.: Climate-sensitive northern lakes and ponds are critical components of methane release, Nat. Geosci., 9, 99-106, 2016.

Yvon-Durocher, G., Montoya, J. M., Woodward, G. U. Y., Jones, J. I., and Trimmer, M.: Warming increases the proportion of primary production emitted as methane from freshwater mesocosms, Glob. Change Biol., 17, 1225-1234, 2011.

Yvon-Durocher, G., Allen, A. P., Bastviken, D., Conrad, R., Gudasz, C., St-Pierre, A., Thanh-Duc, N., and del Giorgio, P. A.: Methane fluxes show consistent temperature dependence across microbial to ecosystem scales, Nature, 507, 488-491, 2014. 